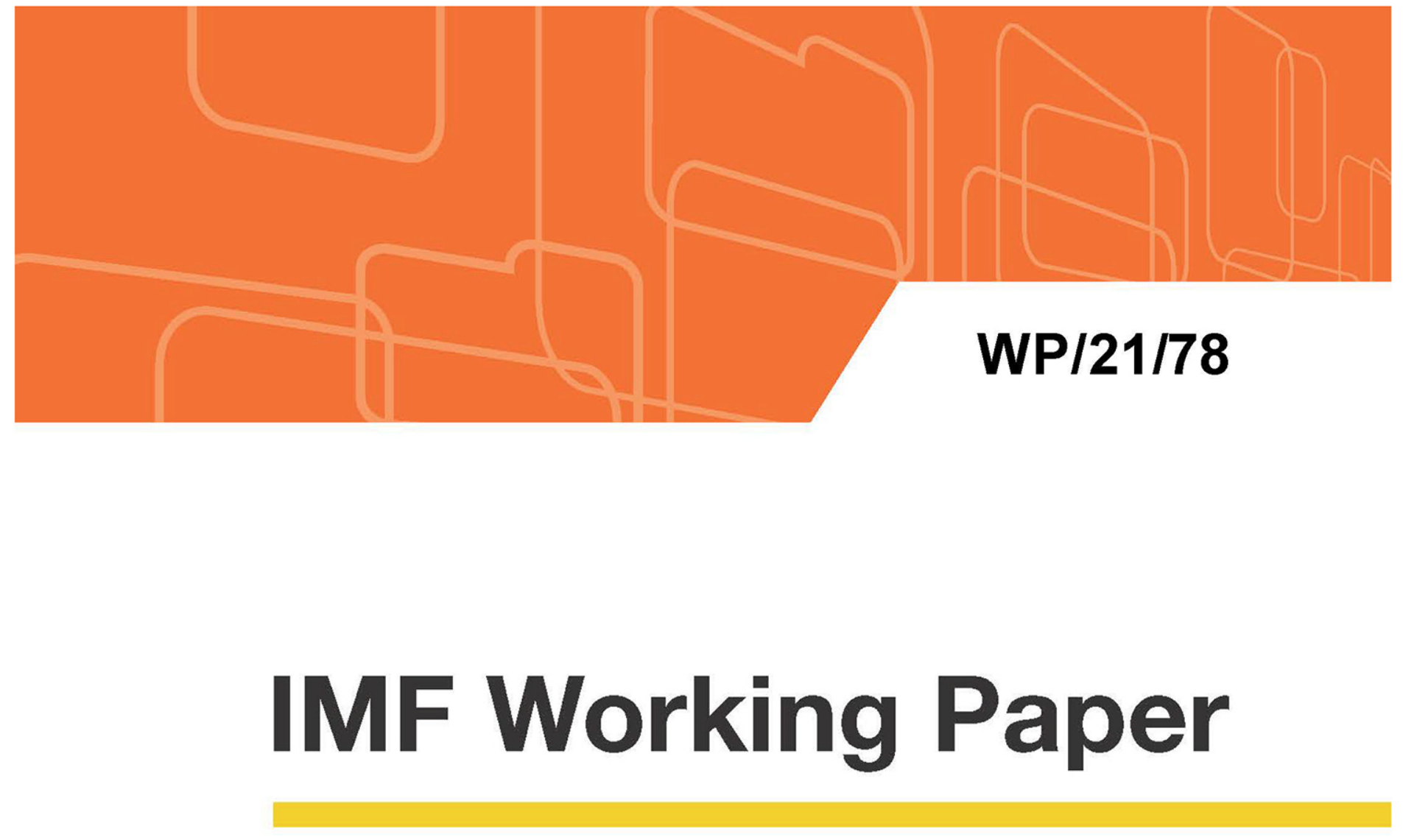

\title{
Monetary Policy, Inflation, and Distributional Impact: South Africa's Case
}

by Ken Miyajima

IMF Working Papers describe research in progress by the author(s) and are published to elicit comments and to encourage debate. The views expressed in IMF Working Papers are those of the author(s) and do not necessarily represent the views of the IMF, its Executive Board, or IMF management. 


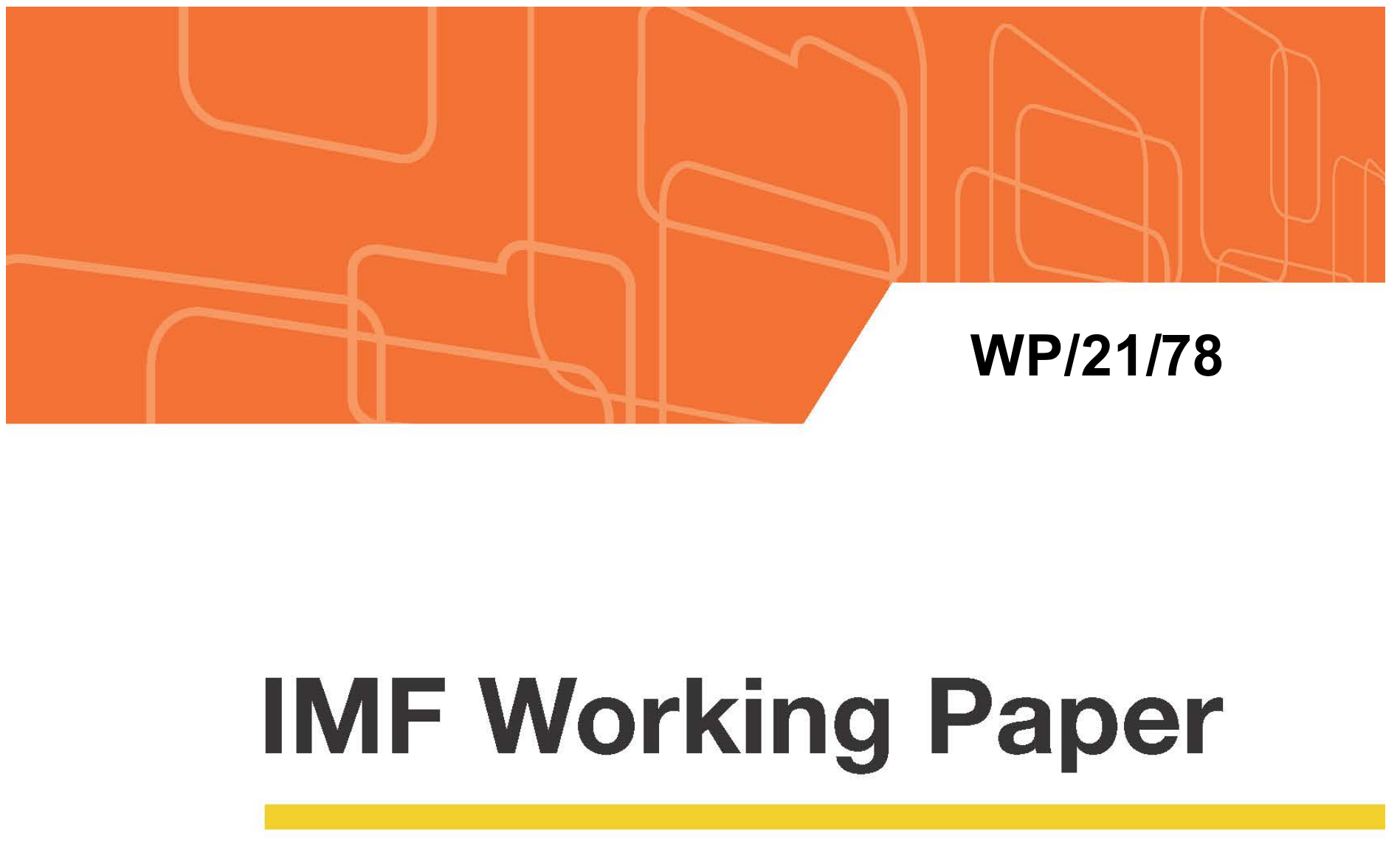

\section{Monetary Policy, Inflation, and Distributional Impact: South Africa's Case}

by Ken Miyajima

IMF Working Papers describe research in progress by the author(s) and are published to elicit comments and to encourage debate. The views expressed in IMF Working Papers are those of the author(s) and do not necessarily represent the views of the IMF, its Executive Board, or IMF management.

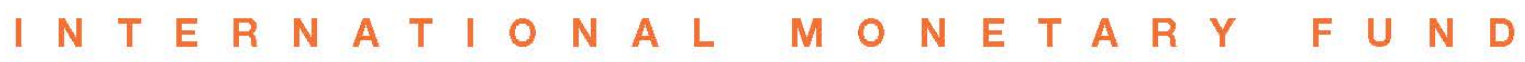




\title{
IMF Working Paper
}

\author{
African Department \\ Monetary Policy, Inflation, and Distributional Impact: South Africa's Case \\ Prepared by Ken Miyajima
}

Authorized for distribution by Ana Lucía Coronel

March 2021

\section{IMF Working Papers describe research in progress by the author(s) and are published to elicit comments and to encourage debate. The views expressed in IMF Working Papers are those of the author(s) and do not necessarily represent the views of the IMF, its Executive Board, or IMF management. The views in this paper also do not necessarily reflect those of the BIS.}

\begin{abstract}
The South African Reserve Bank has continued to fulfill its constitutional mandate to protect the value of the local currency by keeping inflation low and steady. This paper provides evidence that monetary policy tightening aimed at maintaining low and stable inflation could at the same time reduce consumption inequality over a $12-18$ month horizon, commonly understood as the transmission lag of monetary policy action to the real economy, and similar to the distance between survey waves used in the analysis. In response to "exogenous" monetary policy tightening, the real consumption of individuals at lower ends of the consumption distribution declines relatively modestly, or even increases. With greater reliance on government transfers, thus smaller reliance on labor income, and relatively larger food consumption, these individuals appear to benefit mainly from lower inflation. By contrast, the real consumption of individuals at higher ends of the consumption distribution is more likely to decline due to lower labor income, weaker asset price performance, and higher debt service cost.
\end{abstract}

JEL Classification Numbers: E31, E58

Keywords: Distributional effects, inflation, monetary policy, South Africa.

Author's E-Mail Address: Kmiyajima@imf.org 


\section{Table of Contents}

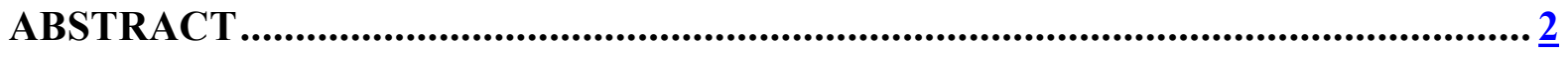

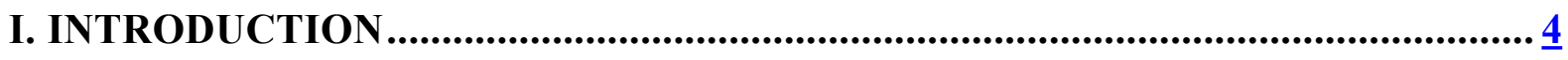

II. POTENTIAL CHANNELS OF MONETARY POLICY TRANSMISSION IN SOUTH AFRICA-DESCRIPTIVE DATA ANALYSIS................................................. 7

III.IDENTIFYING THE EXOGENOUS MONETARY POLICY SHOCK................. 9

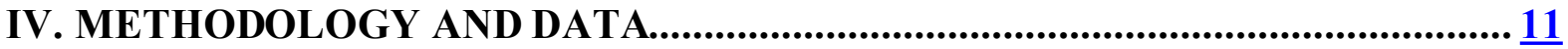

V. ESTIMATED RESULTS .............................................................................. 13

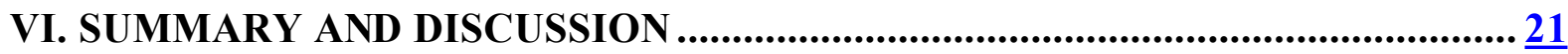

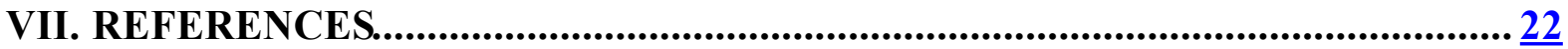




\section{INTRODUCTION ${ }^{1}$}

South Africa achieved noteworthy progress after the end of apartheid. Poverty fell, and access to education and healthcare expanded. An expansion in social housing, water, and electricity coverage improved living conditions. Taxes and social spending redistribute income in a progressive manner. Yet government debt declined to below 30 percent of GDP by the late-2000s amid robust economic growth. Unemployment, which had risen to above 30 percent after the transition to democracy, declined to somewhat above 20 percent by the late-2000s. Strong economic institutions supported these advances.

Despite the progress, low growth and the legacies of apartheid continue to weigh on income distribution. Amid the COVID-19 pandemic, per-capita output growth in 2020 is set to reman negative for a 6 th year. Fiscal space has been eroded amid large fiscal deficits and relatively high and growing public debt. Private investment has been dampened by low consumer and business confidence, limiting productivity growth. The education system has been unsuccessful to equip the youth with sufficient human capital. Unemployment, poverty, and inequality are unacceptably high. South Africa started the 1990s with already elevated inequality as the policy of apartheid excluded a large swath of the population from economic opportunities. South Africa's Gini-an index that measures inequality-has increased further in the early 2000 s and remained high ever since. Meanwhile, its peers have been able to make inroads in reducing inequality. ${ }^{2}$

One notable achievement has been a trend decline in inflation both in level and volatility terms (Figure 1). Inflation fluctuated in a 10-20 percent range until the early-1990s. Subsequently, as interest rates remained relatively high, inflation declined, registering single digit outturns for the first time in almost a decade at the end of 1992. Inflation continued to moderate, with its average rate during 1993-99 at around 8 percent. Following the formal inception of inflation targeting in February 2000, inflation was initially volatile - it spiked towards the end of 2001 after the rand weakened sharply, and again in 2008 on higher commodity prices. $^{3}$ However, inflation became more stable since 2010 and moderated toward the mid-point of the 3-6 percent target range in the late-2010s aided by significant crop food price disinflation, exchange rate appreciation, and central bank communication to de-facto target the midpoint of the target range. Some of the trend decline may be due to global disinflation trend. Inflation volatility has remained relatively low. The coefficient of variation - standard deviation normalized by the inflation level-shows a similar decline in volatility since the early-2000s. During the COVID-19 pandemic which stated in early 2020, inflation declined to the lower end of the 3-6 percent target band but its volatility edged up.

\footnotetext{
${ }^{1}$ The author is gra teful to the 2018 South African Na tional Treasury-SARB-IMF seminar participants, Cristian Alonso, Ana Lucía Coronel, Da vid Fowkes, Chiara Fratto, Chris Loewald, Nan Li, Machiko Narita, the IMF African Department Fina ncial and Monetary Network seminar participants (including Andy Berg, Anne-Marie Gulde-Wolf, Da vid Robinson, Geremia Palomba, Michael Gorbanyov, Mika Saito, Hoda Selim, Inderjit Sia n, Ja son Weiss, and Jia xiong Yao), a nd the African Department Research Advisory Group for their comments to ea rlier and current versions. Any errors are the author's responsibility.

${ }^{2}$ https://www.imf.org/en/News/Articles/2020/01/29/na012820six-charts-on-south-africas-persistent-and-multifaceted-inequality

${ }^{3}$ The intention to a dopt inflation targeting wa s announced in August 1999.
} 
Figure 1. Short-Term Interest Rate and Inflation
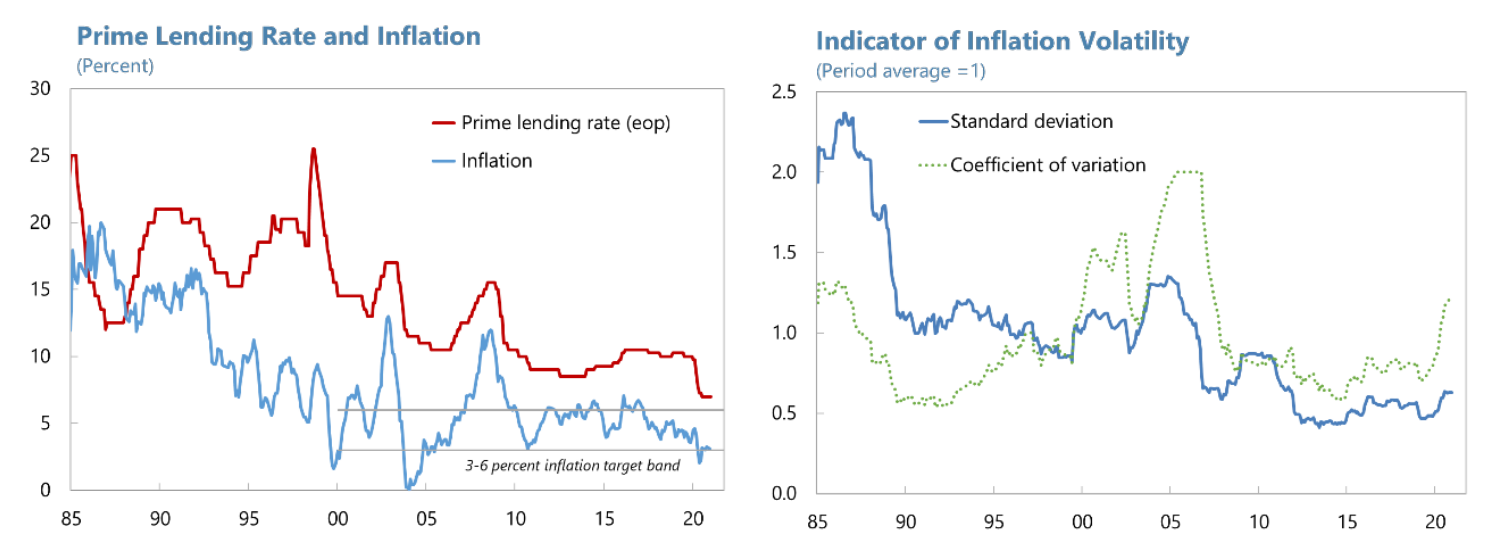

Sources: Haver and the author.

Note: Prime lending rate is generally 350 basis points above the policy rate. Standard deviation = 3-year rolling average of monthly inflation rate differentials. Coefficient of variation = stand ard deviation scaled by 3-year rolling average inflation rate (capped at 2 around year 2005 for read ability).

Low and stable inflation would generally have favorable distributional effects to the extent that the poor are more negatively affected by higher inflation than the rich. The rich may be better able to protect themselves against the effects of higher inflation, owing to greater access to financial instruments that hedge in some way against inflation, than the poor who likely have a larger share in cash. State subsidies, transfers, and pension payouts may not be fully indexed and inflation may reduce their real incomes. Easterly and Fischer (2001) provide supporting evidence based on large cross-country data and household survey results. Albanesi (2007) highlights that inflation and inequality are positively related across different countries. Findings by Bulír (2001) are more nuanced, where the reduction in inflation from hyperinflationary levels significantly lowers income inequality, but further reduction toward a very low level of inflation seems to bring about negligible additional gains. Inflation could instead reduce the real value of debt and favor the less well-off in a borrower-lender context- even moderate inflation leads to a sizable redistribution of wealth from rich, old households (net creditors) to middle-class, young households (net debtors) in the United States (Doepke and Schneider, 2006).

On a related question as to how monetary policy would affect inequality, findings in the literature are mixed. Redistribution is a channel through which monetary policy affects the macroeconomy (Brunnermeier and Sannikov, 2012; Auclert, 2019; Blanchard, 2020). Auclert (2019) focuses on three sources of redistribution-labor and profit earnings, unexpected inflation, and financial asset prices - to assess how monetary policy transmission differ across economic agents with different characteristics using a theoretical model and highlights the importance of capital gains and losses. Kaplan et al. (2018) presents a Heterogeneous Agent New Keynesian (HANK) framework, where monetary policy easing affects aggregate consumption primarily through an increase in labor demand. ${ }^{4}$ Monetary policy impact on inequality is mixed potentially as the mechanisms linking monetary policy and inequality are complex, depending on a multitude of factors including macroeconomic

\footnotetext{
${ }^{4}$ This contra sts findings from Representative Agent New Keynesian (RANK) economies, whereintertemporal substitution drives virtually all of the transmission from interest ra tes to consumption.
} 
conditions and the distributions of income and wealth. For instance, contractionary monetary policy could either reduce inequality by dampening asset and goods price inflation, or increase it by benefiting savers (wealthier) over borrowers (less wealthy). In the Unites States, unconventional monetary policy easing helped reduce inequality by stimulating economic activity (Bivens, 2015). Similarly, contractionary monetary policy in the United States systematically increases inequality in labor earnings, total income, consumption and total expenditures (Coibion et al., 2017). By contrast, the announcement of the ECB's Outright Monetary Transactions program benefited the wealthier (Adam and Tzamourani, 2016). ${ }^{6}$ In fact, the type of a monetary policy shock may matter. In a panel of 32 advanced and emerging countries, unexpected monetary policy tightening could increase inequality, but observed increases in policy rates would reduce in equality (Furceri et al., 2018). The magnitude of redistributive consequences of conventional monetary policy seems to be small, and evidence around the inequality-worsening impact of unconventional monetary policy easing is still inconclusive (Amaral, 2017). Lower inequality is associated with stronger effectiveness and higher homogeneity of monetary policy transmission (Voinea et al., 2017). Relatedly, Hansen et al. (2020) use a tractable Two-Agent New Keynesian model that captures important dimensions of inequality and find some support for making inequality an explicit target for monetary policy. ${ }^{7}$

In the South African context, monetary policy action aimed at maintaining low and stable inflation could reduce consumption inequality through several channels (Kganyago, 2018). First, monetary policy tightening would have a much stronger contractionary impact through higher borrowing costs on households at higher ends of the income distribution than on the rest of the population. Individuals with higher income borrow far more in volume than those with lower income. In addition, interest rates faced by lower income borrowers are affected heavily by other factors such as information asymmetries and default risk than just the level of the policy rate itself. Second, as most assets are owned by people at the top end of the income distribution, low interest rates and higher asset prices would increase inequality. Third, South Africa's growth tends to strengthen and generate more jobs when inflation is low, mostly from stronger private sector investment and productivity growth. Also, an important share of high unemployment is structural, on which monetary policy has little impact. Finally, monetary policy action that helps lower inflation can increase the consumption of the poorest South Africans, even as it reduces the purchasing power of the richer South Africans. This is because poorer people have less choice over spending and it is harder for them to protect their wages and savings against inflation.

Against this backdrop, this paper asks whether monetary policy action aimed at maintaining low and stable inflation could also have distributional effects in South Africa. It relies on the National Income Dynamics Study (NIDS), the first national panel study in South Africa,

\footnotetext{
${ }^{5}$ Endogenous output a nd sticky prices allow monetary policy to havereal effects on the economy.

${ }^{6}$ Similar to an unexpected loosening of the monetary policy rate by 175 basis points.

${ }^{7}$ Aklin et al(2021) argue stronger central bank independence worsens inequality through three channels - it constrains fiscal policy's ability to engage in redistribution, prompts grea ter financial market deregulation and genera tes a sset price booms, and leads to policies that weaken the bargaining power of workers in a bid to contain inflationary pressures.
} 
which provides empirical data on the changing lives of South Africans during 2008-17, tracking a large number of same individuals across five waves (see Section IV.B for details). ${ }^{8}$ In particular, "per-capita household" consumption (household consumption per adult adjusted for age group) in real terms is regressed on the estimated "exogenous" monetary policy shock (net of the anticipated component due to macroeconomic conditions, which can influence both monetary policy action and consumption), controlling for a range of macroeconomic factors and individual-level characteristics. After investigating potential transmission channels, distributional effects are estimated using the interaction of the exogenous monetary policy shock with consumption decile dummies.

Estimated results suggest that monetary policy tightening would reduce consumption inequality in South Africa. In response to exogenous monetary policy tightening, the real consumption of individuals with lower consumption levels declines relatively modestly, or even increase. These individuals rely more on government transfers in the form of social grants, thus less so on labor income, and consume a larger share of food, and appear to benefit mainly from lower inflation. The real consumption of individuals with higher consumption levels appears to be affected mainly by lower labor income, weaker asset price performance, and higher debt service cost.

This paper is structured as follows. The next section discusses potential key transmission channels of monetary policy relying on a descriptive data analysis. Section III estimates the exogenous monetary policy shock. Section IV discusses the econometric methodology and data. Section V discusses the estimated results and Section VI concludes.

\section{Potential Channels of Monetary Policy Transmission in South Africa- DESCRIPTIVE DATA ANALYSIS}

Inflation could be a key channel of monetary policy transmission for individuals with lower consumption in South Africa. These individuals tend to face higher inflation in both level and volatility (Table 1). Average inflation over the sample period of 2008-17, which corresponds to that used in our econometric analysis, is 6.1 percent for the lowest two consumption deciles, above the 5.4 percent for the highest two consumption deciles. Volatility of inflation, measured by both standard deviation and the coefficient of variation (standard deviation scaled by average), faced by the lowest two consumption deciles is twice as high as that faced by the highest two consumption deciles. The chance of facing the highest inflation is the highest for the lowest two consumption deciles (56-57 percent). This is partly because food prices account for a large share of the CPI basket--around 45 percent of total for the lowest two consumption deciles, significantly above the 15-25 percent of total for the highest two consumption deciles (Table 2). During 2020, those in the lower consumption deciles, the most affected by the COVID-19 pandemic, generally faced relatively high inflation. However, those in the highest deciles also faced relatively high inflation in terms of both level and volatility.

\footnotetext{
${ }^{8}$ During the COVID-19 pandemic a dditional wa ves of phone-based surveys, or the Coronavirus Rapid Mobile Surveys, were released. They are notused in this paperbased on varia ble a vailability.
} 


\begin{tabular}{|c|c|c|c|c|c|c|c|c|}
\hline Table & Inflatior & Charact & eristics b & y Consu & mption De & cile: 2009 & 17 and & 020 \\
\hline \multirow[t]{2}{*}{ Consumption decile } & $\begin{array}{l}\text { Average inflation } \\
\text { (Percent) }\end{array}$ & $\begin{array}{l}\begin{array}{c}\text { Standard } \\
\text { deviation }\end{array} \\
\text { (Decile 1 = 1) }\end{array}$ & $\begin{array}{l}\text { Coefficient of } \\
\text { variation } \\
\text { (Decile 1 = 1) }\end{array}$ & $\begin{array}{c}\text { Probability of } \\
\text { facing highest } \\
\text { inflation } \\
\text { (Percent) }\end{array}$ & $\begin{array}{c}\text { Average inflation, } \\
\text { when decile faces } \\
\text { highest inflation } \\
\text { (Percent) }\end{array}$ & $\begin{array}{c}\text { Average inflation } \\
\text { (Percent) }\end{array}$ & $\begin{array}{l}\text { Standard } \\
\text { deviation } \\
\text { (Decile 1 = 1) }\end{array}$ & $\begin{array}{l}\text { Coefficient of } \\
\text { variation } \\
\text { (Decile 1 = 1) }\end{array}$ \\
\hline & \multicolumn{5}{|c|}{ (January 2009 - December 2017) } & \multicolumn{3}{|c|}{ (January - December 2020) } \\
\hline 1 & 6.1 & 1.0 & 1.0 & & 7.0 & 3.8 & 1.0 & 1. \\
\hline 2 & 6.1 & 1.0 & 1.0 & & 7.0 & 3.8 & 0.8 & 0. \\
\hline 3 & 6.0 & 0.9 & 0.9 & & 8.3 & 3.4 & 0.8 & 0. \\
\hline 4 & 6.0 & 0.9 & 0.9 & & 8.3 & 3.2 & 0.8 & 1. \\
\hline 5 & 5.9 & 0.8 & 0.9 & & 6.7 & 3.0 & 0.7 & 0. \\
\hline 6 & 5.9 & 0.8 & 0.8 & & 6.7 & 2.9 & 0.7 & 0. \\
\hline 7 & 5.7 & 0.6 & 0.7 & & 5.4 & 2.9 & 0.9 & 1. \\
\hline 8 & 5.8 & 0.6 & 0.7 & & 5.4 & 2.9 & 1.1 & 1. \\
\hline 9 & 5.4 & 0.4 & 0.5 & & 5.0 & 3.2 & 1.2 & 1. \\
\hline 10 & 5.4 & 0.4 & 0.5 & & 5.1 & 3.5 & 1.2 & 1. \\
\hline
\end{tabular}

\begin{tabular}{|c|c|c|c|c|c|c|c|}
\hline Consumption decile & $\begin{array}{l}\text { Food consumption } \\
\text { (Percent of total) }\end{array}$ & $\begin{array}{l}\text { Employment } \\
\text { (Percent) }\end{array}$ & $\begin{array}{l}\text { Grant recipient } \\
\text { (Percent) }\end{array}$ & $\begin{array}{l}\text { Total assets } \\
\text { (Rand) }\end{array}$ & $\begin{array}{l}\text { Financial assets } \\
\text { (Rand) }\end{array}$ & $\begin{array}{l}\text { Debt } \\
\text { (Rand) }\end{array}$ & $\begin{array}{l}\text { Net worth } \\
\text { (Rand) }\end{array}$ \\
\hline 1 & 46 & 28 & 85 & 13,601 & 136 & 707 & 12,996 \\
\hline 2 & 44 & 34 & 85 & 20,762 & 419 & 1,048 & 19,66 \\
\hline 3 & 42 & 38 & 83 & 28,168 & 350 & 1,531 & 26,52 \\
\hline 4 & 41 & 41 & 87 & 29,814 & 492 & 1,399 & 28,323 \\
\hline 5 & 37 & 42 & 79 & 36,774 & 1,249 & 2,191 & 36,265 \\
\hline 6 & 36 & 44 & 75 & 51,982 & 1,371 & 3,558 & 50,046 \\
\hline 7 & 33 & 49 & 67 & 67,190 & 1,494 & 4,728 & 63,82 \\
\hline 8 & 30 & 54 & 57 & 74,418 & 1,616 & 5,971 & $69,71 C$ \\
\hline 9 & 25 & 54 & 38 & 153,236 & 2,336 & 16,036 & 140,148 \\
\hline 10 & 15 & 65 & 21 & 930,792 & 28,522 & 81,129 & 854,85 \\
\hline Average & 35 & 45 & 68 & 140,674 & 3,799 & 11,830 & 130,23 \\
\hline $\begin{array}{l}\text { Sources: NIDS } \\
\text { Note: Some de } \\
\text { debt, and net v } \\
\text { dimensions. }\end{array}$ & $\begin{array}{l}\text { Wave } 5 \text { and th } \\
\text { ecile level estim } \\
\text { North data are }\end{array}$ & $\begin{array}{l}\text { uthor's calcu } \\
\text { s for assts ar } \\
\text { used in eco }\end{array}$ & $\begin{array}{l}\text { tions. } \\
\text { Inet worth a } \\
\text { ometrics due }\end{array}$ & $\begin{array}{l}\text { eplaced wit } \\
\text { datalimitat }\end{array}$ & $\begin{array}{l}\text { interpolation } \\
\text { ns in both tir }\end{array}$ & $\begin{array}{l}\text { to odd re } \\
\text { d cross-se }\end{array}$ & Asset, \\
\hline
\end{tabular}

Individuals with lower consumption are less likely to be impacted by monetary policy action through labor income, asset prices, or debt service cost. Table 2 summarizes key variables from the dataset used for our econometric analysis. Low employment rates suggest labor income is probably a less important channel on monetary policy transmission for these individuals. Employment rates for the lowest two consumption deciles are 28-34 percent, around $1 / 2$ of $54-65$ percent for the highest two deciles. Social grants, an important fiscal policy tool to support the poor's livelihood, are a relatively stable source of nominal income, gain in real value as inflation declines, and are relatively insulated from business cycles. ${ }^{9}$ More than 80 percent of those in the lowest 4 consumption deciles receive social grants,

\footnotetext{
${ }^{9}$ Results from the 2018 General Household Survey suggest that a bout 44 percent of households received at least one kind of grants and that gra nts were the main source of income for a lmost 20 percent of households nationally.
} 
significantly more than the shares for the highest deciles. Individuals consuming less tend to own less assets, debt, and net worth. ${ }^{10}$ It is important to note that the less well-off could be relatively highly indebted. For instance, NIDS data suggest that those in the lowest consumption decile are as indebted relative to income as those in the highest consumption decile. However, to the extent that the former borrow from lenders charging very high interest rates, monetary policy action in 25 or 50 basis point increments would have subdued effects on their debt service cost.

\section{Identifying The Exogenous Monetary Policy Shock}

The "exogenous" monetary policy shock is estimated following the literature. The anticipated component due to macroeconomic conditions, which can influence both monetary policy action and consumption in our econometric specifications, is removed from the observed monetary policy shock. This is expected to help avoid finding the "inflation puzzle", where a rate hike (cut) is associated with a rise (fall) in inflation. We do so following Furceri et al. (2018) and Auerbach and Gorodnichenko (2013). First, unexpected changes in the policy rate $i$ in year $t$ are proxied by the forecast error $F E_{t}^{i}$, that is, the difference between the policy rate $i$ observed at the end of year $t\left(A C T_{t}^{i}\right)$, and the policy rate expected during the course of the year $\left(E X P_{t}^{i}\right)$ :

$$
F E_{t}^{i}=A C T_{t}^{i}-E X P_{t}^{i}
$$

Forecast errors of headline inflation $\left(F E_{t}^{\pi}\right)$ and GDP growth $\left(F E_{t}^{y}\right)$ are computed similarly. Exogenous monetary policy shocks (MPS) are the residuals $\varepsilon_{t}$ from the regression of the forecast errors of the policy rates on those of inflation and output growth.

$$
F E_{t}^{i}=\alpha+\beta F E_{t}^{\pi}+\Upsilon F E_{t}^{y}+\varepsilon_{t}
$$

Inflation and GDP growth data are taken from different vintages of the October WEO. Policy rate expectations are taken from the October vintages of Consensus Economics data.

The estimated exogenous monetary policy shock displays the following characteristics. ${ }^{11}$ In some years, it moves in the opposite direction than the observed policy rate, suggesting the importance of analyzing unanticipated effects. Our estimates for South Africa are similar to those by Furceri et al. (2018) and Romer and Romer (2004) for the United States, potentially reflecting the view that global central banks' reaction functions may have become less diverse as the shocks these central banks face have become more similar. The estimated exogenous monetary policy shock for South Africa averages around zero with standard deviation of 0.34 for 2000-19. The statistics for the NIDS wave years (shaded areas in Figure 2 ) are similar, at zero and 0.25 . The comparable statistics for the policy rate for 2000-19 and 2008-17 are averages of -41 and -27 basis points, and standard deviation of 1.6 and 1.5 . Econometric results in Table 3 suggest that a positive exogenous monetary policy shock,

\footnotetext{
${ }^{10}$ Net worth represents an off-the shelf variable in the datasetrather than the author's calculations.
}

${ }^{11}$ The estimates do not display a uto correlation. 
indicating tightening, is associated with a reduction in inflation but has a muted relationship with real GDP growth. A one standard deviation exogenous monetary policy shock, or tightening, is associated with around 1 percentage point reduction $(=-3.395 * 0.34)$ in the rate of inflation. An observed increase in the policy rate (detrended, to alleviate the chance of spurious correlation) is associated with a rise in inflation (the inflation puzzle).

\section{Figure 2. Policy Rate and Exogenous Monetary Policy Shock in South Africa \\ (Percent)}

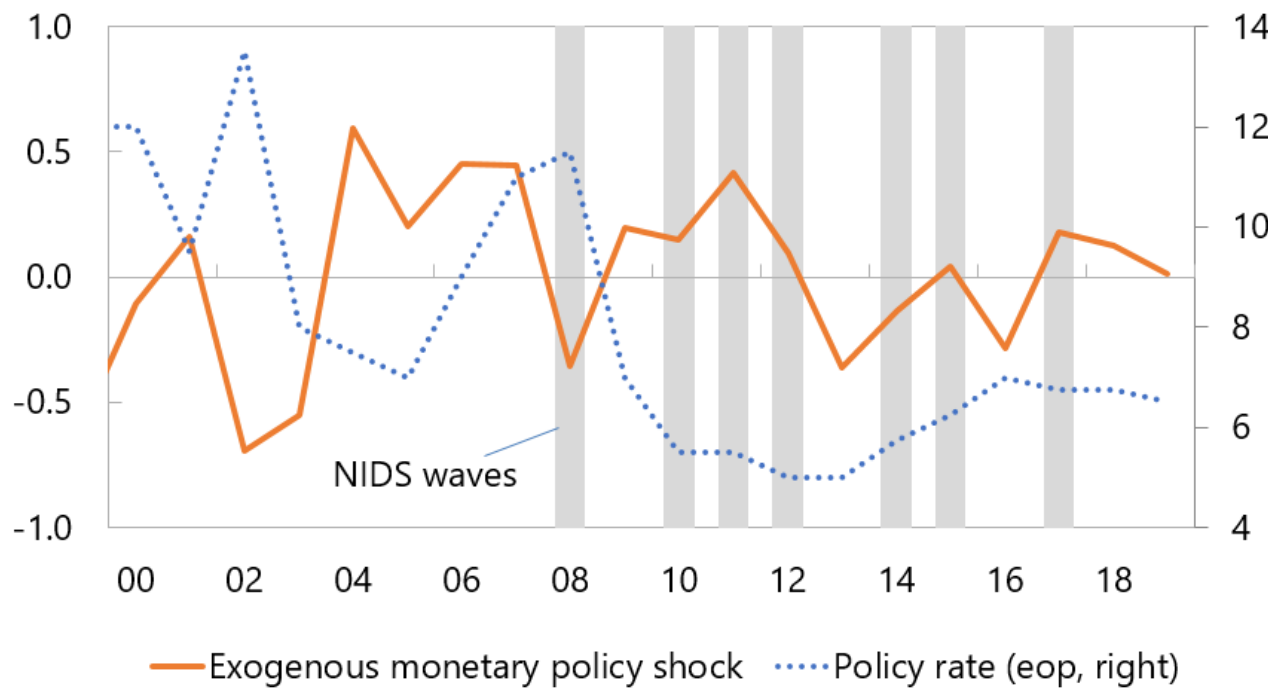

Sources: Haver Analytics Database and author's calculations.

Note: Exogenous monetary policy shock is the error term from equation (2).

\begin{tabular}{|c|c|c|c|c|c|c|c|}
\hline \multirow{4}{*}{$\begin{array}{l}\text { Independent variable } \\
\text { Exogenous monetary policy shock } \\
\text { std. error }\end{array}$} & \multirow{4}{*}{$\frac{\text { Coeff. }}{\beta}$} & \multicolumn{6}{|c|}{ Dependent variable } \\
\hline & & \multicolumn{3}{|c|}{ Inflation $(\pi)$} & \multicolumn{3}{|c|}{ Real GDP growth (g) } \\
\hline & & $-3.780 * * *$ & $-3.395 * * *$ & $\ldots$ & 0.455 & 0.279 & $\ldots$ \\
\hline & & 0.993 & 0.995 & $\ldots$ & 1.171 & 1.040 & $\ldots$ \\
\hline \multirow{2}{*}{$\begin{array}{l}\text { Policy rate, detrended } \\
\text { std. error }\end{array}$} & \multirow[t]{2}{*}{$\beta$} & $\ldots$ & $\ldots$ & 1.127 *** & $\ldots$ & $\ldots$ & -0.242 \\
\hline & & $\ldots$ & $\ldots$ & 0.239 & $\ldots$ & $\ldots$ & 0.288 \\
\hline \multirow{2}{*}{$\begin{array}{l}\text { Inflation (L1) } \\
\text { std. error }\end{array}$} & \multirow[t]{2}{*}{$r$} & $\ldots$ & 0.258 & 0.000 & $-0.483 * *$ & $-0.420 * *$ & -0.344 \\
\hline & & $\ldots$ & 0.174 & 0.167 & 0.203 & 0.181 & 0.202 \\
\hline \multirow{2}{*}{$\begin{array}{l}\text { Real GDP growth (L1) } \\
\text { std. error }\end{array}$} & \multirow[t]{2}{*}{$\delta$} & 0.447 ** & $0.487 * *$ & 0.258 & $\ldots$ & 0.461 ** & 0.504 ** \\
\hline & & 0.190 & 0.185 & 0.162 & $\ldots$ & 0.194 & 0.195 \\
\hline \multirow{2}{*}{$\begin{array}{l}\text { Constant } \\
\text { std. error }\end{array}$} & \multirow[t]{2}{*}{$\alpha$} & $4.503 * * *$ & $2.920 * *$ & $5.001 * * *$ & $5.369 * * *$ & $3.747 * * \star$ & $3.187 * *$ \\
\hline & & 0.616 & 1.221 & 1.192 & 1.219 & 1.277 & 1.437 \\
\hline \multicolumn{2}{|l|}{$\mathrm{N}$} & 20 & 20 & 20 & 20 & 20 & 20 \\
\hline \multicolumn{2}{|l|}{ Adjusted $\mathrm{R}^{\wedge} 2$} & 0.46 & 0.50 & 0.64 & 0.20 & 0.38 & 0.40 \\
\hline $\begin{array}{l}\text { ource: Author's calculations. } \\
\text { Jote: L1 signifies a one period } \\
\text { vhere } m p s \text { and } p o l \text { are exogen } \\
* g_{-1}+\varepsilon, \quad g=\alpha+\beta *(m p s\end{array}$ & $\begin{array}{l}\text { This ta } \\
\text { monet } \\
p o l)+\end{array}$ & $\begin{array}{l}\text { le reports } \\
\text { y policy sh } \\
* \pi_{-1}+\delta *\end{array}$ & $\begin{array}{l}\text { stimations } \\
\text { ck and the } \\
g_{-1}+\varepsilon\end{array}$ & $\begin{array}{l}\alpha, \beta, \gamma a \\
\text { olicy rate: }\end{array}$ & $\begin{array}{l}\text { Srom the } \\
=\alpha+\beta *(\end{array}$ & $\begin{array}{l}\text { llowing ec } \\
\text { ips or pol) }\end{array}$ & $\begin{array}{l}\text { uations } \\
+\gamma * \pi_{-1}+\end{array}$ \\
\hline
\end{tabular}




\section{Methodology ANd DAta}

\section{A. Methodology}

In our model, per-capita household real consumption in log (see Section IV-B for computation) is regressed on the exogenous monetary policy shock obtained in Section III and a range of controls. The analysis investigates the impact over a 12-18 month horizon, commonly understood as the transmission lag of monetary policy action, which is broadly similar to the distance between NIDS survey waves. This is different from the medium term effect by Furceri et al. (2018). Macroeconomic conditions are controlled for by real GDP level in log. Micro-level individual characteristics are controlled for by dummy variables representing the food to total consumption ratio, employment status, grant receipt status, education attainment, and geography. The geography dummies are also interacted with real GDP levels in log as commonly done in the literature. Distributional effects are estimated by interacting the exogenous monetary policy shock with consumption decile dummies. Extreme values are removed by "winsorizing" the data. ${ }^{12}$

A panel fixed effects approach is used without the lagged dependent variable as the latter is statistically insignificant (results with the lagged dependent variable is reported in Table A1):

$$
\ln c_{i, t}=\sum_{j} a_{j} X_{j}+\sum_{k, i} a_{k} Y_{k, i}+\sum_{l, h} a_{l} Z_{l, h}+\alpha_{i}+c+\varepsilon_{i, t}
$$

A vector of macroeconomic controls $X_{j}$ includes the log of real GDP level and the exogenous monetary policy shock. A vector of micro-level controls $k$ for indivudual $i, Y_{k, i}$ includes dummy variables capturing grant receipt status, employment status, educational attainment, and the food to total consumption ratio. A vector $Z_{l, h}$ reprsents interaction terms between the exogenous monetary policy shock and micro-level controls $l$ for indivudual $h$, including the food to total consumption ratio, the emplyment dummy, the grant dummy, and the consumption decile dummies. $\alpha_{i}$ is time invariant fixed effects of individual $i, c$ is constant, and $\varepsilon_{i, t}$ is the error term.

\section{B. Data}

The analysis relies on the National Income Dynamics Study (NIDS) data. NIDS is the first national household panel study in South Africa. It started in 2008 with a nationally representative sample of over 28,000 individuals in 7,300 households across the country. The survey is conducted approximately every two years, tracking same individuals with unique IDs. At present, five waves are available: 2008, 2010-11, 2012, 2014-15, and 2017. NIDS examines the livelihoods of individuals and households over time and provides information

${ }^{12}$ At $3^{\text {rd }}$ and 97 th percentiles. 
on a wide range of topics. ${ }^{13}$ The sample is restricted to the adults who are successfully surveyed across the 5 waves (about 6,700 adults). ${ }^{14}$

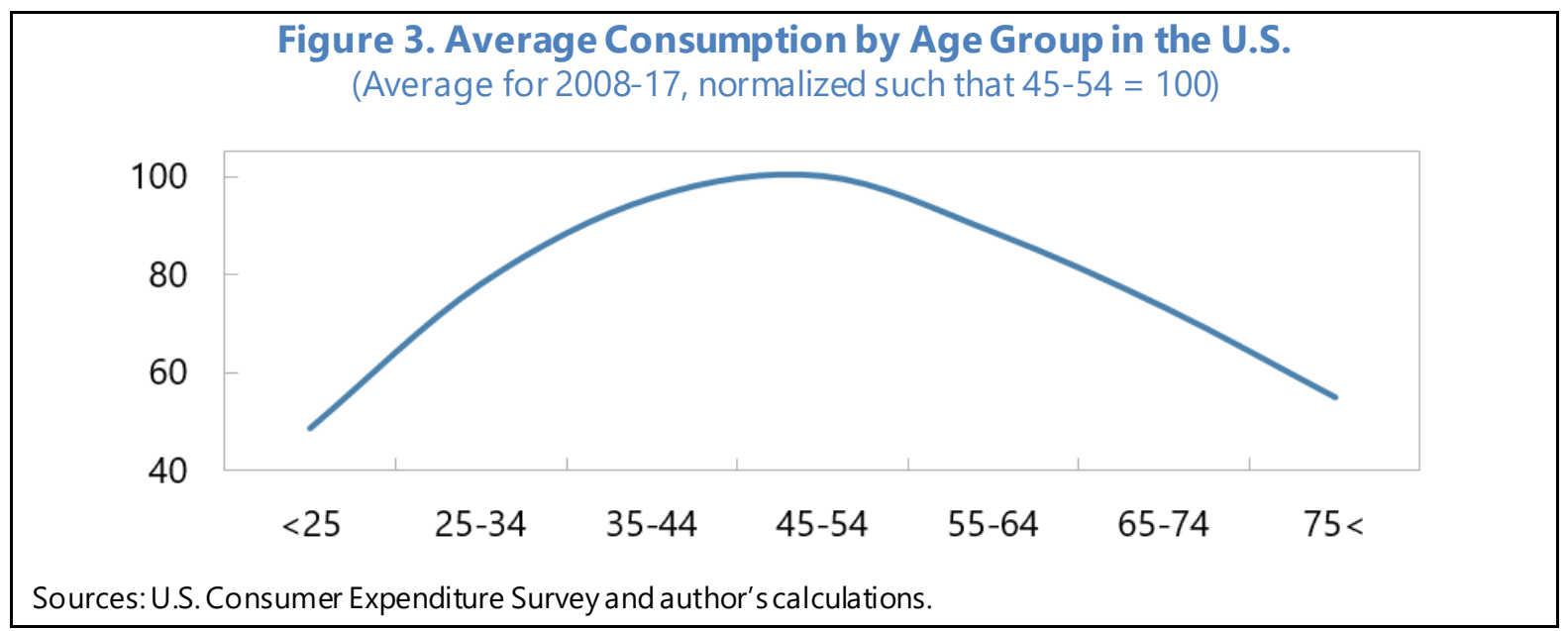

The dependent variable is per-capital household real consumption in log. It is calculated as the household-level consumption divided by the number of adults following studies using NIDS data (Schotte et al., 2018; Zizzamia, 2020). It is further adjusted for age. Average consumption by age group is not available for South African and proxied by data from the U.S. Consumer Expenditure Survey (Figure 3). We use the data to adjust per-capita household consumption in South Africa for 7 age groups. For instance, adults in the 45-54 age group tend to consume the most, twice as much as those that consume the least (below 25 and above 75). Finally, per-capita household consumption is divided by the annual inflation index of the survey year. Individuals are surveyed in different years even in the same wave. Per-capita household real consumption calculated this way is skewed towards higher deciles, but from wave 1 to wave 5 it grew faster for lower deciles, somewhat increasing their shares of total. In our econometric analysis, per-capita household real consumption is introduced in logarithm.

\begin{tabular}{|c|c|c|c|c|c|c|c|c|c|c|}
\hline \multicolumn{11}{|c|}{$\begin{array}{l}\text { Table 4. Average Per-Capita Household Real Consumption Level } \\
\text { (Not in log, normalized such hat decile } 1 \text { in wave } 1=1.0 \text { ) }\end{array}$} \\
\hline & \multicolumn{10}{|c|}{ Consumption Decile } \\
\hline Wave & 1 & 2 & 3 & 4 & 5 & 6 & 7 & 8 & 9 & 10 \\
\hline 1 & 1.0 & 1.4 & 1.8 & 2.3 & 2.9 & 3.6 & 4.6 & 6.6 & 11.2 & 46.4 \\
\hline 2 & 1.0 & 1.5 & 1.9 & 2.4 & 2.9 & 3.6 & 4.6 & 6.5 & 11.5 & 58.1 \\
\hline 3 & 1.1 & 1.6 & 2.1 & 2.7 & 3.3 & 4.2 & 5.4 & 7.6 & 12.9 & 53.6 \\
\hline 4 & 1.5 & 2.1 & 2.7 & 3.3 & 4.1 & 5.1 & 6.6 & 9.1 & 15.5 & 59.1 \\
\hline 5 & 1.7 & 2.3 & 3.0 & 3.6 & 4.4 & 5.4 & 7.0 & 9.5 & 15.5 & 51.8 \\
\hline
\end{tabular}

\footnotetext{
${ }^{13}$ They include poverty, fertility, mortality, migration, la bor market participation, economic activity, health, education, vulnerability, and socialca pital.

${ }^{14}$ Phone-based survey results were recently released a NIDS CRAM to help understand the impact of the COVID-19 pandemic. CRAM are not used as it does notinclude some of the key variables used in the paper.
} 
The independent variables include both macroeconomic conditions and individual characteristics. Macroeconomic conditions are controlled for by real GDP level (in log) in the survey year. Indicators of educational attainment are created for 5 groups - no education (including “other" and "don't know”), lower primary (grades 1-7), upper primary (grades 8 and 9), secondary (grades 10-12, National Technical Certificate, and National Vocational Certificate), and tertiary (everything above secondary). Food consumption is measured as a share of total consumption. The employment dummy takes value of 1 when the individual is "employed" and zero otherwise (either "not economically active", "unemployed strict", "unemployed discouraged", or "refused"). Social grants represent an important fiscal policy tool to help address inequality and the grant recipient dummy takes value of 1 for recipients and 0 otherwise. Geography dummies are created for 4 types, rural and urban, both formal and informal for each survey year. In addition, real GDP level (in log) is interacted with geography dummies to capture time by location effects as standard in the literature.

\begin{tabular}{|c|c|c|c|c|c|c|c|c|c|c|c|c|}
\hline \multirow{4}{*}{ Wave } & \multicolumn{12}{|c|}{$\begin{array}{l}\text { Table 5. Individual Characteristics } \\
\text { (Percent) }\end{array}$} \\
\hline & \multicolumn{5}{|c|}{ Education } & \multirow{3}{*}{$-\frac{\text { Consumption }}{\text { Food 1/ }}$} & \multirow{3}{*}{$\begin{array}{c}\text { Jobs } \\
\text { Employed }\end{array}$} & \multirow{3}{*}{$\begin{array}{l}\text { Social grants } \\
\text { Receipient 2/ }\end{array}$} & \multicolumn{4}{|c|}{ Geography } \\
\hline & \multirow{2}{*}{ No schooling } & \multicolumn{2}{|c|}{ Promary } & \multirow{2}{*}{ Secondary } & \multirow{2}{*}{ Tertiary \& up } & & & & \multicolumn{2}{|c|}{ Rural } & \multicolumn{2}{|c|}{ Urban } \\
\hline & & lower & upper & & & & & & formal & informal & formal & informal \\
\hline 1 & 13 & 27 & 18 & 34 & 7 & $\overline{41}$ & 38 & $\overline{69}$ & 10 & 46 & 38 & $\overline{6}$ \\
\hline 2 & 13 & 24 & 16 & 36 & 10 & 42 & 33 & 62 & 10 & 45 & 39 & 6 \\
\hline 3 & 13 & 24 & 14 & 36 & 12 & 39 & 39 & 68 & 10 & 43 & 40 & 7 \\
\hline 4 & 13 & 24 & 14 & 33 & 17 & 36 & 45 & 68 & 10 & 42 & 41 & 7 \\
\hline 5 & 13 & 23 & 13 & 32 & 19 & 35 & 45 & 68 & 10 & 41 & 41 & 7 \\
\hline Average & 13 & 24 & 15 & 34 & 13 & 39 & 40 & 67 & 10 & 44 & 40 & 6 \\
\hline \multicolumn{13}{|c|}{ Sources: NIDS and author's calculations. } \\
\hline \multicolumn{13}{|c|}{ 1/ Food consumption as a share of total consumption. } \\
\hline 2/ $\mathrm{Nu}$ & mber ofgr & ant reci & jients as & a share & of total $r$ & umbero & Its. & & & & & \\
\hline
\end{tabular}

Table 5 summarizes the individual characteristics. As for educational attainment in wave 5 , the share of primary level education is the highest (36 percent), followed by secondary (32 percent), tertiary (19 percent), and no schooling (13 percent). The share of tertiary education rose by 12 points from wave 1 , as those of primary and secondary education declined. Food consumption as a share of total declined from more than 40 percent in wave 1 to 35 percent in wave 5 . Around 40 percent of the sample are employed in wave 5 , up 7 points from wave 1 . Around $2 / 3$ of the sample receive social grants. Geographically, most of the sample population resides in rural informal and urban formal areas (around 40 percent each in wave 5). ${ }^{15}$

\section{ESTIMATEd RESULTS}

In the baseline model, effects of the exogenous monetary policy shock ( $m p s)$ are estimated by interacting mps with potential channels of transmission, that is, the food to total consumption ratio, the employment dummy, and the grant dummy. As a second step, $m p s$ is

\footnotetext{
${ }^{15}$ Informality in South Africa is rela tively low, at a bout 20-25 percent a long with Mauritius and Namibia, and significantly below 50-65 percent in Benin, Tanzania and Nigeria (Medina et al, 2017).
} 
interacted with consumption decile dummies to investigate distributional effects. These models are also estimated with the lagged dependent variable to show that the latter is statistically insignificant (Table A1). The baseline model is extended with additional variables that could capture potential channels of monetary policy transmission - a different measure of grants, indicators of access to finance, and a different set of consumption deciles. Finally, the observed policy rate is used in place of $m p s$ to re-estimate the models.

\section{Baseline Model- Exogenous Monetary Policy Shock}

Results from a fixed-effects approach suggest that exogenous monetary policy tightening ( $m p s$ ) impacts consumption positively through lower inflation and negatively through reduced labor income (Table 6 and Figure 4). As a reminder, a one unit change in mps represents around 3 standard deviations.

- The coefficient on mps is statistically insignificant when introduced "alone" (Table 6, model 2). This appears consistent with time-series analyses of macro-level data which find consumption responds little to changes in the interest rate after controlling for income (Campbell and Mankiw 1989; Yogo 2004; Canzoneri et al. 2007; Kaplan et al. 2018). ${ }^{16}$

- When the interaction term between $m p s$ and the food to total consumption ratio is introduced, the overall effect of $m p s$ for those with a relatively high food consumption ratio is very low--for instance, the impact of mps is zero for those with a food consumption ratio of 0.45 , corresponding to the lower end of consumption deciles in wave 5 (Figure 4). By contrast, the overall effect of $m p s$ is relatively large and negative for those with a low food consumption ratio - for those with a food consumption ratio of 0.2 , corresponding to the higher end of consumption deciles in wave 5 , the overall impact of exogenous monetary policy tightening is -0.12 . This implies that a one unit (one standard deviation) mps increase leads to a 12 percent (4 percent) reduction in per-capita household real consumption (Table 6 , model 3 ).

- When the interaction term between mps and the employment dummy is introduced, the overall effect of exogenous monetary policy tightening for the employed is -0.11 . This implies a one unit (one standard deviation) $m p s$ increase leads to a 11 percent (3.5 percent) reduction in per-capita household real consumption (Figure 4). mps affects the consumption of the unemployed very little (Table 6, model 4).

- The interaction term between mps and the grant dummy does not generate statistically significant effects (Figure 4, and model 5 in Table 6).

\footnotetext{
${ }^{16}$ Micro survey data on household portfolios show that a sizable fraction of households hold close to zero liquid wea th and face high borrowing costs (Kaplan et al. 2014), reducing their insensitivity to small changes in interest ra tes (Kaplan et al, 2018). Vissing-Jorgensen (2002) finds those with no a sset holdings react little to interest rate cuts.
} 


\begin{tabular}{|c|c|c|c|c|c|c|c|}
\hline \multicolumn{8}{|c|}{$\begin{array}{l}\text { Iable 6. Determinants or Per-Capita Housenold Real Consu } \\
\text { Exogenous Monetary Policy Shock } \\
\text { (Estimated coefficients) }\end{array}$} \\
\hline Model \# & & 1 & 2 & 3 & 4 & 5 & 6 \\
\hline \multicolumn{8}{|l|}{ Macro } \\
\hline Real GDP & Lo. & $1.590^{\star \star \star}$ & $1.921^{* \star *}$ & $1.941^{\star \star \star}$ & $1.891^{\star \star \star}$ & $1.925^{\star \star \star}$ & $1.727^{\star \star \star}$ \\
\hline Exogenous monetary policy shock (mps) & L1. & $\cdots$ & -0.039 & $-0.222^{\star * *}$ & 0.015 & -0.036 & $-0.445^{\star \star \star}$ \\
\hline \multicolumn{8}{|l|}{ Micro } \\
\hline \multicolumn{8}{|l|}{ Education dummy } \\
\hline No education & L1. & $-0.134^{*}$ & $-0.135^{*}$ & $-0.137^{*}$ & -0.129 & $-0.135^{*}$ & -0.108 \\
\hline Lower primary & L1. & $-0.275^{\star \star \star}$ & $-0.277^{\star \star \star}$ & $-0.278^{\star \star \star}$ & $-0.267^{\star \star \star}$ & $-0.277^{\star \star \star}$ & $-0.245^{\star \star \star}$ \\
\hline Upper primary & L1. & $-0.224^{* * *}$ & $-0.225^{* \star *}$ & $-0.228^{\star \star *}$ & $-0.219^{\star \star \star}$ & $-0.225^{* \star *}$ & $-0.212^{\star \star \star}$ \\
\hline Secondary & L1. & $-0.088^{\star \star \star}$ & $-0.088^{\star \star \star}$ & $-0.093^{\star \star \star}$ & $-0.090^{\star \star \star}$ & $-0.088^{\star \star *}$ & $-0.103^{\star \star \star}$ \\
\hline Tertiary & L1. & $\ldots$ & $\ldots$ & $\ldots$ & $\ldots$ & $\ldots$ & $\ldots$ \\
\hline Food share of total cons. & L1. & $0.256^{\star \star \star}$ & $0.259^{\star \star \star}$ & $0.268^{\star \star \star}$ & $0.259^{\star \star \star}$ & $0.259^{\star \star \star}$ & $0.257^{\star \star \star}$ \\
\hline Employment dummy & L1. & $0.049^{\star \star \star}$ & $0.048^{\star \star \star}$ & $0.049^{\star \star \star}$ & $0.043^{\star \star \star}$ & $0.048^{\star \star \star}$ & $0.047^{\star \star \star}$ \\
\hline Grant recipient dummy & L1. & -0.022 & -0.022 & -0.022 & -0.022 & -0.023 & -0.023 \\
\hline \multicolumn{8}{|l|}{ Interaction with $m p s$} \\
\hline $\mathrm{mps}$ * Food share & L1. & $\ldots$ & $\ldots$ & $0.491^{\star \star \star}$ & $\ldots$ & $\ldots$ & $\ldots$ \\
\hline mps * Employment dummy & L1. & $\ldots$ & $\ldots$ & $\ldots$ & $-0.122^{\star \star}$ & $\ldots$ & $\ldots$ \\
\hline mps * Grant recipient dummy & L1. & $\cdots$ & $\cdots$ & $\cdots$ & $\cdots$ & -0.004 & $\cdots$ \\
\hline mps * consumption decile 1 & L1. & $\ldots$ & $\ldots$ & $\ldots$ & $\ldots$ & $\ldots$ & $0.854^{\star \star \star}$ \\
\hline mps * consumption decile 2 & L1. & $\ldots$ & $\ldots$ & $\ldots$ & $\ldots$ & $\ldots$ & $0.827^{\star \star \star}$ \\
\hline $\mathrm{mps}{ }^{*}$ consumption decile 3 & L1. & $\ldots$ & $\ldots$ & $\ldots$ & $\ldots$ & $\ldots$ & $0.729^{\star \star \star}$ \\
\hline mps * consumption decile 4 & L1. & $\ldots$ & $\ldots$ & $\ldots$ & $\ldots$ & $\ldots$ & $0.629^{\star \star \star}$ \\
\hline mps * consumption decile 5 & L1. & $\ldots$ & $\ldots$ & $\ldots$ & $\ldots$ & $\ldots$ & $0.438^{\star \star \star}$ \\
\hline mps * consumption decile 6 & L1. & $\ldots$ & $\ldots$ & $\ldots$ & & $\ldots$ & $0.364^{\star \star \star}$ \\
\hline mps * consumption decile 7 & L1. & $\ldots$ & $\ldots$ & $\ldots$ & $\ldots$ & $\ldots$ & $0.239^{*}$ \\
\hline $\mathrm{mps}{ }^{*}$ consumption decile 8 & L1. & $\ldots$ & $\ldots$ & $\ldots$ & $\ldots$ & $\ldots$ & $0.253^{\star *}$ \\
\hline mps * consumption decile 9 & L1. & $\cdots$ & $\ldots$ & $\ldots$ & $\ldots$ & $\cdots$ & $0.324^{\star \star \star}$ \\
\hline \multicolumn{8}{|l|}{ Other controls } \\
\hline Location & L1. & yes & yes & yes & yes & yes & yes \\
\hline Locationreal GDP & L1. & yes & yes & yes & yes & yes & yes \\
\hline Consumption decile & L1. & yes & yes & yes & yes & yes & yes \\
\hline Individual effects & $\ldots$ & yes & yes & yes & yes & yes & yes \\
\hline \# of Obs. & & 26,876 & 26,876 & 26,876 & 26,876 & 26,876 & 26,876 \\
\hline Cross section $(\mathrm{N})$ & & 6,719 & 6,719 & 6,719 & 6,719 & 6,719 & 6,719 \\
\hline Time series $(T)$ & & 4 & 4 & 4 & 4 & 4 & 4 \\
\hline Adjusted $R^{\wedge} 2$ & & 0.115 & 0.115 & 0.115 & 0.115 & 0.116 & 0.126 \\
\hline \multicolumn{8}{|l|}{ Memo item: } \\
\hline \multicolumn{8}{|l|}{ Total effect of $\mathrm{mps}$} \\
\hline Food share $=0.45$ & $\ldots$ & $\ldots$ & $\ldots$ & -0.001 & $\ldots$ & $\ldots$ & $\ldots$ \\
\hline Food share $=0.2$ & $\ldots$ & $\ldots$ & $\ldots$ & $-0.124^{\star \star}$ & $\ldots$ & $\ldots$ & $\ldots$ \\
\hline Employment dummy & $\ldots$ & $\ldots$ & $\ldots$ & $\ldots$ & $-0.108^{*}$ & $\ldots$ & $\ldots$ \\
\hline Grant recipient dummy & $\ldots$ & $\ldots$ & $\ldots$ & $\cdots$ & $\ldots$ & -0.041 & $\ldots$ \\
\hline Consumption decile 1 & $\ldots$ & $\ldots$ & $\ldots$ & $\ldots$ & $\ldots$ & $\ldots$ & $0.409^{\star \star \star}$ \\
\hline Consumption decile 2 & & $\ldots$ & $\ldots$ & & $\ldots$ & & $0.382^{\star \star \star}$ \\
\hline Consumption decile 3 & $\ldots$ & $\ldots$ & $\ldots$ & $\ldots$ & $\ldots$ & $\ldots$ & $0.284^{\star \star \star}$ \\
\hline Consumption decile 4 & $\ldots$ & $\ldots$ & $\ldots$ & $\ldots$ & $\ldots$ & $\ldots$ & $0.184^{*}$ \\
\hline Consumption decile 5 & $\ldots$ & $\ldots$ & $\ldots$ & $\ldots$ & $\ldots$ & $\ldots$ & -0.007 \\
\hline Consumption decile 6 & $\ldots$ & $\ldots$ & $\ldots$ & $\ldots$ & $\ldots$ & $\ldots$ & -0.081 \\
\hline Consumption decile 7 & $\ldots$ & $\ldots$ & $\ldots$ & $\ldots$ & $\ldots$ & $\ldots$ & $-0.205^{\star \star}$ \\
\hline Consumption decile 8 & $\ldots$ & $\ldots$ & $\ldots$ & $\ldots$ & $\ldots$ & $\ldots$ & $-0.191^{\star}$ \\
\hline Consumption decile 9 & $\ldots$ & $\ldots$ & $\ldots$ & $\ldots$ & $\ldots$ & $\ldots$ & -0.121 \\
\hline Consumption decile 10 & $\ldots$ & $\ldots$ & $\ldots$ & $\ldots$ & $\ldots$ & $\ldots$ & $-0.445^{\star \star \star}$ \\
\hline $\begin{array}{l}\text { Sources: Haver, NIDS, and author' } \\
\text { Note: This table reports estimatec } \\
\text { consumption level in log. } L 0 \text { and L } \\
\text { significant at the } 1,5 \text {, and } 10 \text { perc } \\
\text { command lincom. }\end{array}$ & $\begin{array}{l}\text { Scalc } \\
\text { Iresu } \\
1 \text { sig } \\
\text { ent le }\end{array}$ & $\begin{array}{l}\text { culations } \\
\text { ults from } \\
\text { nify cont } \\
\text { evels. Me }\end{array}$ & $\begin{array}{l}\text { tion (3) } \\
\text { ooraneo } \\
\text { tem rep }\end{array}$ & $\begin{array}{l}\text { endent } \\
\text { lue and } \\
\text { he total }\end{array}$ & $\begin{array}{l}\text { le is pe } \\
\text { eriod la } \\
\text { ts of } m\end{array}$ & $\begin{array}{l}\text { ta house } \\
{ }^{*}, \text { and } * \\
\text { ulated us }\end{array}$ & $\begin{array}{l}\text { real } \\
\text { n statistically } \\
\text { Stata }\end{array}$ \\
\hline
\end{tabular}




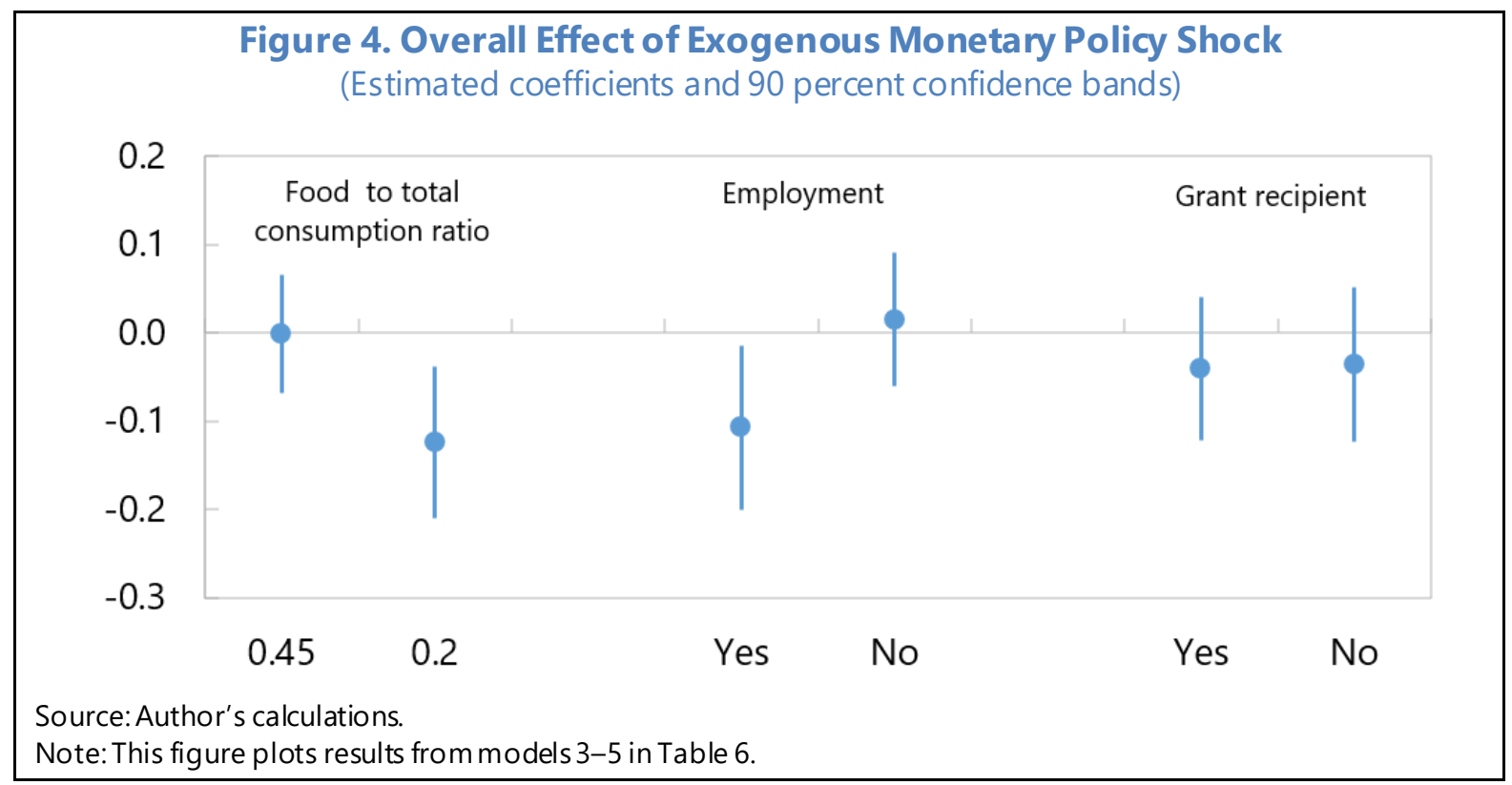

Results from a fixed-effects model with consumption decile dummies suggest that exogenous monetary policy tightening exerts less negative, or even positive effects on individuals on the lower end of the consumption distribution (Table 6, model 6). Figure 5 plots estimated coefficients on mps and its interaction terms with consumption deciles (left panel), and the sum of the two, that is, overall effects of the exogenous monetary policy shock (right panel). ${ }^{17}$ Estimated coefficients on interaction terms are statistically significant and take larger values for lower consumption deciles (left panel). Therefore the overall effect on the right panel is the largest for the first two deciles, where one unit (standard deviation) increase in $m p s$ leads to a 40 percent (13 percent) increase in consumption. The overall effect moderates to 0.3 for the third decile, 0.2 for the fourth decile, and zero for the 5-6 deciles. The overall effect turns negative, to -0.2 for the $7-8^{\text {th }}$ deciles and -0.45 for the $10^{\text {th }}$ decile. The overall effect for the $9^{\text {th }}$ decile is not statistically different from zero. The earlier discussions and estimated results suggest that the real consumption of those on the lower end of the consumption distribution would increase, benefitting from lower and more stable inflation, and being less negatively affected through lower labor income, weaker asset price performance, and higher debt service cost.

Other control variables are important determinants of consumption (Table 6). A one percent increase in real GDP leads to a 1.5-2 percent increase in per-capita household real consumption. Higher educational attainment helps lift consumption - those with primary and secondary education tend to consume around 20 percent and 10 percent less than those with tertiary education, respectively. The coefficient on the no education dummy is not statistically significant. The coefficient on the employment dummy is positive but small (suggesting that the employed consume around 5 percent more than the unemployed) potentially as some of the effect is absorbed by other individual characteristics and time invariant fixed-effects. The grant dummy does not yield significant coefficients.

\footnotetext{
${ }^{17}$ Stata command lincom is used to estimate theoverall effects and confidence intervals.
} 


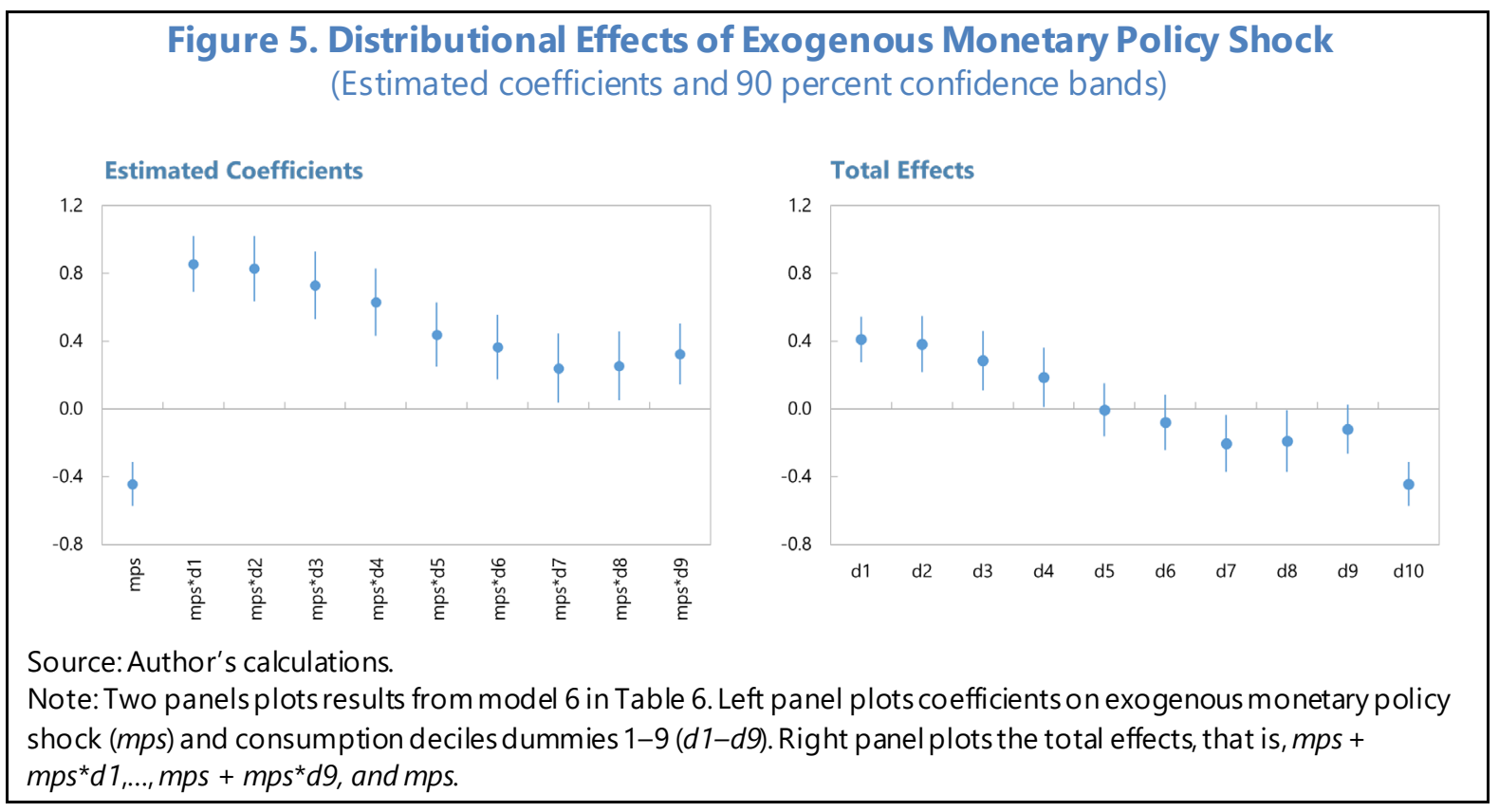

\section{Extension 1: Additional Channels of Monetary Policy Transmission}

The baseline model is extended with additional variables that could capture potential channels of monetary policy transmission (Figure 6). First, a dummy variable capturing grant receipt is replaced by the ratio of the amount of grants received to total consumption.

The ratio falls from above 1 for lower consumption deciles to $0.6-0.8$ for the middle deciles, and further to around 0.2 for the highest consumption decile. Second, bank account and credit card ownership dummies are introduced. Both increase with consumption level, even though bank account ownership is more important throughout. Finally, consumption decile dummies are used for the $2^{\text {nd }}$ through $10^{\text {th }}$ deciles (instead of the $1^{\text {st }}$ through $9^{\text {th }}$ deciles in the baseline model).

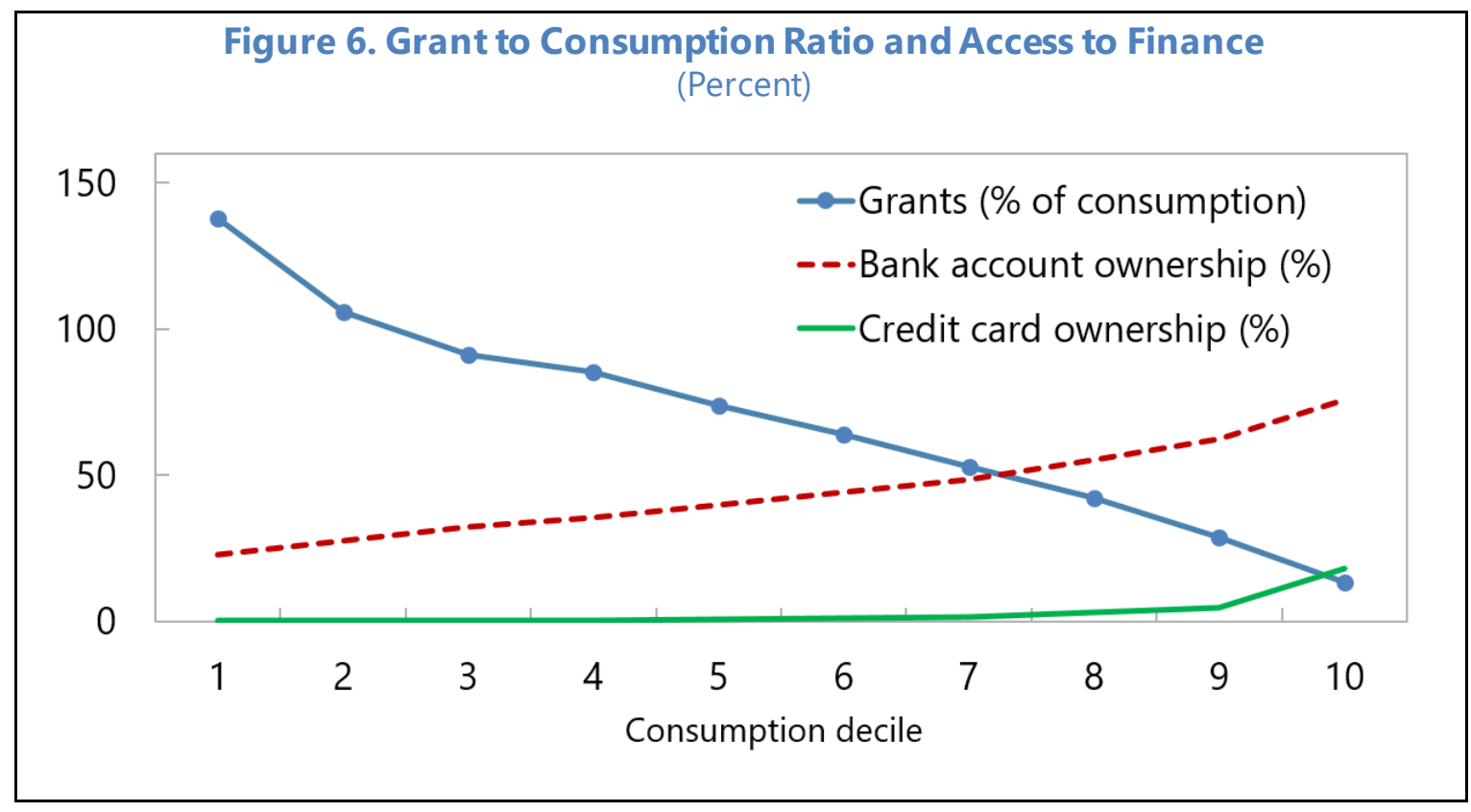


Several observations emerge from the extended models (Table 7). ${ }^{18}$ First, the total effect of $m p s$ is weaker for those individuals more reliant on social grants (and implicitly less reliant on labor income). The total effect of $m p s$ is -0.11 for those with the grant to consumption ratio of 0.25 , corresponding roughly to the $8^{\text {th }}$ consumption decile (model 7$)$. The estimate is zero for those with the ratio of 0.9 , corresponding to the $3^{\text {rd }}$ consumption decile. Second, credit card ownership emerges as an important monetary policy transmission channel likely though debt service cost. The total effect of $m p s$ is around -0.45 for credit card owners while it is zero for those without a credit card. Bank account ownership does not come out as an important monetary policy transmission channel, probably because bank accounts among a segment of the population is mainly used for receiving social grants rather than as a basis for financial services. Finally, the total effect of $m p s$ remains broadly unchanged when consumption decile dummies are used for the $2^{\text {nd }}$ through $10^{\text {th }}$ (instead of the $1^{\text {st }}$ through $9^{\text {th }}$ ). Note that, in all cases, the lagged dependent variable, when included, is statistically significant even though mostly at the 10 percent level, indicating that these models either suffer from an omitted variable or Nickell bias, making the results rather suggestive.

\section{Extension 2: Observed Policy Rate}

Results from models using the real policy rate ( $r p o l$ ) are somewhat weaker (Table 8). The policy rate (period average) is deflated by one year ahead inflation expectations from the Bureau of Economic Research South Africa, and detrended by taking first differences. The overall effects of rpol are statistically insignificant with respect to the food to consumption ratio, the employment dummy, and the grant recipient dummy. When consumption deciles dummies are used, the coefficient on rpol is around -0.2 , and the coefficients on consumption deciles (all statistically significant) start from 0.54 for the lowest consumption decile and decline in size to around 0.1 for the $5^{\text {th }}$ decile, and hover around $0.15-0.2$ for the $6-10^{\text {th }}$ consumption deciles. However, the overall effects of $r p o l$ is statistically significant at the 1 percent level for the lowest, $5^{\text {th }}$ and highest consumption deciles only. The coefficients on other control variables are similar to those from the earlier models using $m p s$.

However, overall effects of monetary policy tightening are larger than before in a few cases, even though the magnitude of mps and rpol may not be comparable. The average and standard deviation of $r p o l$ is -0.3 and 1.0 for 2008-17. Thus, a one standard deviation increase in rpol leads to a 34 percent increase in per-capital household real consumption for the first consumption decile. This is larger than the 13 percent obtained earlier due to a one standard deviation move in $m p s$. The impact for the $10^{\text {th }}$ consumption decile, of around 20 percent reduction in consumption, is also larger than the 15 percent reduction due to a one standard variation move in mps.

\footnotetext{
${ }^{18}$ Ea ch model is estima ted with and without the la gged dependent variable.
} 


\begin{tabular}{|c|c|c|c|c|c|c|c|c|c|}
\hline \multicolumn{2}{|l|}{ Model \# } & 7 & 8 & 11 & 12 & 13 & 14 & 9 & 10 \\
\hline & & \multirow{2}{*}{\multicolumn{2}{|c|}{ Grant to consmption }} & \multicolumn{4}{|c|}{ Access to finance } & \multirow{2}{*}{\multicolumn{2}{|c|}{ Different decile dummies }} \\
\hline & & & & & account & & fit card & & \\
\hline \multicolumn{10}{|l|}{ Macro } \\
\hline Real GDP (log) & Lo. & $2.668^{* * *}$ & $2.823^{\star \star *}$ & $1.841^{\star \star \star}$ & $1.923^{\star \star \star}$ & $1.932^{\star \star \star}$ & $2.018^{\star \star \star}$ & $1.750^{\star \star \star *}$ & $1.832^{\star \star \star}$ \\
\hline Exogenous monetary policy shock (mps) & L1. & $-0.146^{\star *}$ & $-0.177^{\star \star \star}$ & 0.000 & -0.012 & -0.02 & -0.033 & $0.389^{* \star *}$ & $0.371^{\star \star \star}$ \\
\hline \multicolumn{10}{|l|}{ Micro } \\
\hline $\begin{array}{l}\text { Per-capita household real cons. (log) } \\
\text { Education dummy }\end{array}$ & L1. & $\ldots$ & $-0.188^{\star * *}$ & $\ldots$ & $-0.076^{\star}$ & $\ldots$ & $-0.077^{\star}$ & $\ldots$ & $-0.074^{\star}$ \\
\hline No education & L1. & -0.153 & $-0.154^{*}$ & -0.123 & -0.123 & $-0.133^{*}$ & $-0.133^{\star}$ & -0.107 & -0.107 \\
\hline Lower primary & L1. & $-0.228^{\star * *}$ & $-0.225^{* * *}$ & $-0.264^{\star * *}$ & $-0.263^{* * *}$ & $-0.271^{* * *}$ & $-0.271^{\star \star *}$ & $-0.243^{\star * \star}$ & $-0.243^{\star \star *}$ \\
\hline Upper primary & L1. & $-0.202^{* * *}$ & $-0.201^{* * *}$ & $-0.212^{\star * *}$ & $-0.213^{* \star *}$ & $-0.221^{* \star *}$ & $-0.221^{\star \star \star}$ & $-0.209^{\star \star \star}$ & $-0.210^{\star \star \star}$ \\
\hline Secondary & L1. & $-0.112^{\star \star}$ & $-0.114^{* * *}$ & $-0.085^{* * *}$ & $-0.086^{* * *}$ & $-0.088^{* \star *}$ & $-0.090^{\star \star *}$ & $-0.101^{\star \star \star}$ & $-0.102^{\star \star *}$ \\
\hline Tertiary & L1. & $\ldots$ & $\ldots$ & $\ldots$ & $\ldots$ & $\ldots$ & $\ldots$ & $\ldots$ & $\ldots$ \\
\hline Food share of total consumption ratio & L1. & $0.166^{\star \star \star}$ & $0.149^{* * *}$ & $0.253^{* \star *}$ & $0.245^{* * *}$ & $0.251^{\star * \star}$ & $0.243^{* * *}$ & $0.250^{\star \star *}$ & $0.243^{\star \star *}$ \\
\hline Employment dummy & L1. & $0.046^{\star \star}$ & $0.049^{* *}$ & $0.042^{* * *}$ & $0.043^{* * *}$ & $0.049^{* * *}$ & $0.050^{* \star *}$ & $0.048^{* * *}$ & $0.049^{\star \star \star}$ \\
\hline Grant to consumption ratio & L1. & $0.032^{*}$ & 0.027 & $\ldots$ & $\ldots$ & $\ldots$ & $\ldots$ & $\ldots$ & $\ldots$ \\
\hline Bank account & L1. & $\ldots$ & $\ldots$ & $0.039^{\star *}$ & $0.040^{* \star}$ & $\ldots$ & $\ldots$ & $\ldots$ & $\ldots$ \\
\hline Credit card & L1. & $\ldots$ & $\ldots$ & $\ldots$ & $\ldots$ & -0.031 & -0.030 & $\ldots$ & $\ldots$ \\
\hline \multicolumn{10}{|l|}{ Interaction with mps } \\
\hline mps * grant to consumption ratio & L1. & $0.088^{*}$ & $0.088^{*}$ & $\ldots$ & $\ldots$ & $\ldots$ & $\ldots$ & $\ldots$ & $\ldots$ \\
\hline $\mathrm{mps}$ * bank account & L1. & $\ldots$ & $\ldots$ & -0.088 & -0.092 & $\ldots$ & $\ldots$ & $\ldots$ & $\ldots$ \\
\hline $\mathrm{mps}{ }^{*}$ credit card & L1. & & $\ldots$ & $\ldots$ & $\ldots$ & $-0.420^{\star \star *}$ & $-0.432^{\star \star *}$ & $\ldots$ & \\
\hline mps * consumption decile 1 & L1. & $\ldots$ & $\ldots$ & $\ldots$ & $\ldots$ & $\ldots$ & $\ldots$ & $\ldots$ & $\ldots$ \\
\hline mps * consumption decile 2 & L1. & & $\ldots$ & $\ldots$ & $\ldots$ & $\ldots$ & & -0.009 & -0.003 \\
\hline mps * consumption decile 3 & L1. & $\ldots$ & $\ldots$ & $\ldots$ & $\ldots$ & $\ldots$ & $\ldots$ & -0.110 & -0.104 \\
\hline mps * consumption decile 4 & L1. & $\ldots$ & $\ldots$ & $\ldots$ & $\ldots$ & $\ldots$ & $\ldots$ & -0.204 & -0.196 \\
\hline mps * consumption decile 5 & L1. & $\ldots$ & $\ldots$ & $\ldots$ & $\ldots$ & $\ldots$ & $\ldots$ & $-0.399^{* * *}$ & $-0.393^{* \star *}$ \\
\hline mps * consumption decile 6 & L1. & & $\ldots$ & $\ldots$ & $\ldots$ & $\ldots$ & $\ldots$ & $-0.471^{\star \star \star}$ & $-0.465^{\star \star \star}$ \\
\hline mps * consumption decile 7 & L1. & & $\ldots$ & & $\ldots$ & $\ldots$ & $\ldots$ & $-0.591^{\star \star \star}$ & $-0.584^{* \star \star}$ \\
\hline mps * consumption decile 8 & L1. & $\ldots$ & $\ldots$ & $\ldots$ & $\ldots$ & $\ldots$ & $\ldots$ & $-0.579^{* \star *}$ & $-0.574^{* \star *}$ \\
\hline mps * consumption decile 9 & L1. & $\ldots$ & $\ldots$ & $\ldots$ & $\ldots$ & $\ldots$ & $\ldots$ & $-0.515^{\star \star \star}$ & $-0.512^{* * *}$ \\
\hline mps * consumption decile 10 & L1. & $\ldots$ & $\ldots$ & $\ldots$ & $\ldots$ & $\ldots$ & $\ldots$ & $-0.831^{\star \star *}$ & $-0.827^{\star \star *}$ \\
\hline \multicolumn{10}{|l|}{ Other controls } \\
\hline Location & L1. & yes & yes & yes & yes & yes & yes & yes & yes \\
\hline Location*real GDP & L1. & yes & yes & yes & yes & yes & yes & yes & yes \\
\hline Consumption decile & L1. & yes & yes & yes & yes & yes & yes & yes & yes \\
\hline Individual effects & $\ldots$ & yes & yes & yes & yes & yes & yes & yes & yes \\
\hline \# of Obs. & & 17,998 & 17,998 & 26,876 & 26,876 & 26,876 & 26,876 & 26,876 & 26,876 \\
\hline Cross section $(\mathrm{N})$ & & 4,500 & 4,500 & 6,719 & 6,719 & 6,719 & 6,719 & 6,719 & 6,719 \\
\hline Time series $(T)$ & & 4 & 4 & 4 & 4 & 4 & 4 & 4 & 4 \\
\hline Adjusted $R^{\wedge} 2$ & & 0.120 & 0.121 & 0.116 & 0.117 & 0.117 & 0.117 & 0.126 & 0.127 \\
\hline \multicolumn{10}{|l|}{ Memo item: } \\
\hline \multicolumn{10}{|l|}{ Total effect of $\mathrm{mps}$} \\
\hline Grant to consmption $=0.9$ & $\ldots$ & -0.067 & $-0.098^{* \star}$ & $\ldots$ & $\ldots$ & $\ldots$ & $\ldots$ & $\ldots$ & $\ldots$ \\
\hline Grant to consmption $=0.25$ & $\ldots$ & $-0.111^{\star \star}$ & $-0.155^{\star * *}$ & $\ldots$ & $\ldots$ & $\ldots$ & $\ldots$ & $\ldots$ & $\ldots$ \\
\hline Bank account & $\ldots$ & $\ldots$ & $\ldots$ & -0.087 & $-0.103^{\star}$ & $\ldots$ & $\ldots$ & $\ldots$ & $\ldots$ \\
\hline Credit card & $\ldots$ & $\ldots$ & $\ldots$ & $\ldots$ & $\ldots$ & $-0.443^{* * *}$ & $-0.469^{\star \star \star}$ & $\ldots$ & $\ldots$ \\
\hline Consumption decile 1 & ... & $\ldots$ & $\ldots$ & $\ldots$ & $\ldots$ & $\ldots$ & $\ldots$ & $0.389^{\star \star \star}$ & $0.371^{\star \star \star}$ \\
\hline Consumption decile 2 & $\ldots$ & $\ldots$ & $\ldots$ & $\ldots$ & $\ldots$ & $\ldots$ & $\ldots$ & $0.381^{\star \star \star}$ & $0.368^{\star \star \star}$ \\
\hline Consumption decile 3 & $\ldots$ & $\ldots$ & $\ldots$ & $\ldots$ & $\ldots$ & $\ldots$ & $\ldots$ & $0.28^{\star \star \star}$ & $0.267^{\star \star \star}$ \\
\hline Consumption decile 4 & $\ldots$ & $\ldots$ & $\ldots$ & $\ldots$ & $\ldots$ & $\ldots$ & $\ldots$ & $0.185^{*}$ & $0.175^{\star}$ \\
\hline Consumption decile 5 & $\ldots$ & $\ldots$ & $\ldots$ & $\ldots$ & $\ldots$ & $\ldots$ & $\ldots$ & -0.009 & -0.022 \\
\hline Consumption decile 6 & $\ldots$ & $\ldots$ & $\ldots$ & & $\ldots$ & $\ldots$ & $\ldots$ & -0.081 & -0.094 \\
\hline Consumption decile 7 & $\ldots$ & $\ldots$ & $\ldots$ & $\ldots$ & $\ldots$ & $\ldots$ & $\ldots$ & $-0.201^{\star *}$ & $-0.213^{* *}$ \\
\hline Consumption decile 8 & $\ldots$ & $\ldots$ & $\ldots$ & $\ldots$ & $\ldots$ & $\ldots$ & $\ldots$ & $-0.189^{*}$ & $-0.203^{*}$ \\
\hline Consumption decile 9 & $\ldots$ & $\ldots$ & $\ldots$ & $\ldots$ & $\ldots$ & $\ldots$ & $\ldots$ & -0.126 & -0.141 \\
\hline Consumption decile 10 & ... & $\ldots$ & $\ldots$ & $\ldots$ & $\ldots$ & $\ldots$ & $\ldots$ & $-0.443^{* * *}$ & $-0.458^{\star \star *}$ \\
\hline
\end{tabular}

Sources: Haver, NIDS, and author's calculations.

Note: This table reports estimated results from equation (3). Dependent variable is per-capita household real consumption level in log. L0 and L1 signify contemporaneous value and one period lag. ***,, , and * when statistically significant at the 1,5, and 10 percent levels. Memo item reports the total effects of mps calculated using Stata

command lincom. 
Table 8. Determinants of Per-Capita Household Real Consumption in Sou th Africa: Extension 2-Real Policy Rate

(Estimated coefficients)

\begin{tabular}{|c|c|c|c|c|c|c|}
\hline Model \# & & 11 & 12 & 13 & 14 & 15 \\
\hline \multicolumn{7}{|l|}{ Macro } \\
\hline Real GDP & LO. & $1.588^{\star \star \star}$ & $1.588^{\star \star \star}$ & $1.587^{\star \star \star}$ & $1.577^{\star \star \star}$ & $1.624^{\star \star \star}$ \\
\hline Real policy rate $(r p o l)$ & L1. & 0.003 & -0.052 & 0.011 & -0.028 & $-0.195^{\star \star \star}$ \\
\hline \multicolumn{7}{|l|}{ Micro } \\
\hline \multicolumn{7}{|l|}{ Education dummy } \\
\hline No education & L1. & -0.124 & -0.127 & -0.124 & -0.122 & -0.122 \\
\hline Lower primary & L1. & $-0.264^{\star \star \star}$ & $-0.269^{\star \star \star}$ & $-0.263^{\star \star \star}$ & $-0.263^{\star * \star}$ & $-0.256^{\star \star \star}$ \\
\hline Upper primary & L1. & $-0.215^{\star \star \star}$ & $-0.219^{\star \star \star}$ & $-0.214^{\star \star \star}$ & $-0.215^{\star \star \star}$ & $-0.214^{\star \star \star}$ \\
\hline Secondary & L1. & $-0.076^{\star \star}$ & $-0.081^{\star \star \star}$ & $-0.077^{\star \star}$ & $-0.077^{\star \star}$ & $-0.098^{\star \star \star}$ \\
\hline Tertiary & L1. & $\ldots$ & $\ldots$ & $\ldots$ & $\ldots$ & $\ldots$ \\
\hline Food share of total cons. & L1. & $0.385^{\star \star \star}$ & $0.436^{\star \star \star}$ & $0.385^{\star \star \star}$ & $0.386^{\star \star \star}$ & $0.251^{\star \star \star}$ \\
\hline Employment dummy & L1. & $0.038^{\star \star}$ & $0.038^{\star \star}$ & $0.035^{\star \star}$ & $0.038^{\star \star}$ & $0.045^{\star \star \star}$ \\
\hline Grant recipient dummy & L1. & -0.018 & -0.018 & -0.019 & -0.004 & -0.023 \\
\hline \multicolumn{7}{|l|}{ Interaction with $r p o l$} \\
\hline rpol* Food share & L1. & $\ldots$ & $0.180^{\star *}$ & $\ldots$ & $\ldots$ & $\ldots$ \\
\hline rpol* Employment dummy & L1. & $\ldots$ & $\ldots$ & -0.014 & $\ldots$ & \\
\hline 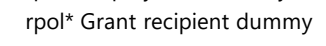 & L1. & $\ldots$ & $\ldots$ & $\ldots$ & $0.057^{\star *}$ & $\ldots$ \\
\hline rpol * consumption decile 1 & L1. & $\ldots$ & $\ldots$ & $\ldots$ & $\ldots$ & $0.536^{\star \star *}$ \\
\hline rpol * consumption decile 2 & L1. & $\ldots$ & $\ldots$ & $\ldots$ & $\ldots$ & $0.275^{\star \star \star}$ \\
\hline rpol * consumption decile 3 & L1. & $\ldots$ & $\ldots$ & $\ldots$ & $\ldots$ & $0.232^{\star \star \star}$ \\
\hline rpol * consumption decile 4 & L1. & $\ldots$ & $\ldots$ & $\ldots$ & $\ldots$ & $0.223^{\star * *}$ \\
\hline rpol * consumption decile 5 & L1. & $\ldots$ & $\ldots$ & $\ldots$ & $\ldots$ & $0.103^{*}$ \\
\hline rpol * consumption decile 6 & L1. & $\ldots$ & $\ldots$ & $\ldots$ & $\ldots$ & $0.146^{\star \star}$ \\
\hline rpol * consumption decile 7 & L1. & $\ldots$ & $\ldots$ & $\ldots$ & $\ldots$ & $0.167^{\star \star \star}$ \\
\hline rpol * consumption decile 8 & L1. & $\ldots$ & $\ldots$ & $\ldots$ & $\ldots$ & $0.223^{\star \star \star}$ \\
\hline rpol * consumption decile 9 & L1. & $\ldots$ & $\ldots$ & $\ldots$ & $\ldots$ & $0.182^{* * \star}$ \\
\hline \multicolumn{7}{|l|}{ Other controls } \\
\hline Location & L1. & yes & yes & yes & yes & yes \\
\hline Location*real GDP & L1. & yes & yes & yes & yes & yes \\
\hline Consumption decile & L1. & no & no & no & no & yes \\
\hline Individual effects & $\ldots$ & yes & yes & yes & yes & yes \\
\hline \# of Obs. & & 26,876 & 26,876 & 26,876 & 26,876 & 26,876 \\
\hline Cross section (N) & & 6,719 & 6,719 & 6,719 & 6,719 & 6,719 \\
\hline Time series $(\mathrm{T})$ & & 4 & 4 & 4 & 4 & 4 \\
\hline Adjusted $R^{\wedge} 2$ & & 0.108 & 0.109 & 0.108 & 0.109 & 0.124 \\
\hline \multicolumn{7}{|l|}{ Memo item: } \\
\hline \multicolumn{7}{|l|}{ Total effect of $r p o l$} \\
\hline Food share $=0.45$ & $\ldots$ & $\ldots$ & 0.028 & $\ldots$ & $\ldots$ & $\ldots$ \\
\hline Food share $=0.2$ & $\ldots$ & $\ldots$ & -0.017 & $\ldots$ & $\ldots$ & $\ldots$ \\
\hline Employment dummy & $\ldots$ & $\ldots$ & $\ldots$ & -0.003 & $\ldots$ & $\ldots$ \\
\hline Grant recipient dummy & $\ldots$ & $\ldots$ & $\ldots$ & $\ldots$ & 0.029 & $\ldots$ \\
\hline Consumption decile 1 & $\ldots$ & $\ldots$ & $\ldots$ & $\ldots$ & $\ldots$ & $0.34^{\star \star \star}$ \\
\hline Consumption decile 2 & $\ldots$ & $\ldots$ & $\ldots$ & $\ldots$ & $\ldots$ & 0.08 \\
\hline Consumption decile 3 & $\ldots$ & $\ldots$ & $\ldots$ & $\ldots$ & $\ldots$ & 0.036 \\
\hline Consumption decile 4 & $\ldots$ & $\ldots$ & $\ldots$ & $\ldots$ & $\ldots$ & 0.027 \\
\hline Consumption decile 5 & $\ldots$ & $\ldots$ & $\ldots$ & $\ldots$ & $\ldots$ & $-0.093^{*}$ \\
\hline Consumption decile 6 & $\ldots$ & $\ldots$ & $\ldots$ & $\ldots$ & $\ldots$ & -0.049 \\
\hline Consumption decile 7 & $\ldots$ & $\ldots$ & $\ldots$ & $\ldots$ & $\ldots$ & -0.028 \\
\hline Consumption decile 8 & $\ldots$ & $\ldots$ & $\ldots$ & $\ldots$ & $\ldots$ & 0.028 \\
\hline Consumption decile 9 & $\ldots$ & $\ldots$ & $\ldots$ & $\ldots$ & $\ldots$ & -0.014 \\
\hline Consumption decile 10 & $\ldots$ & $\ldots$ & $\ldots$ & $\ldots$ & $\ldots$ & $-0.195^{\star \star \star}$ \\
\hline
\end{tabular}

Sources: Haver, NIDS, and author's calculations.

Note: This table reports estimated results from equation (3). Dependent variable is per-capita household real consumption level in log. L0 and L1 signify contemporaneous value and one period lag. ${ }^{* * *}$, ${ }^{* *}$, and * when statistically significant at the 1,5, and 10 percent levels. Memo item reports the total effects of mps calculated using Stat command lincom. 


\section{SUMMARY AND DiscuSSION}

This paper contributes to our understanding of the role of individual characteristics in the transmission mechanism of monetary policy in the context of South Africa. Exogenous monetary policy tightening exerts a modest and less unfavorable effect, or even a relatively large favorable effect, on the consumption of individuals at lower ends of the consumption distribution. Individuals with lower consumption levels tend to rely more on government transfers, thus less on labor income, and appear to benefit mainly from lower inflation. The consumption of individuals with higher consumption levels is more likely to be negatively affected through lower labor income, weaker asset price performance, and higher debt service cost.

As the South African Reserve Bank (SARB) uses monetary policy to safeguard low and stable inflation, welfare-improving policies need to address other key determinants of individual-level consumption. As inflation fell to around the lower end of the official target band, the SARB progressively reduced the policy rate by 300 basis points in 2020 so that the accommodative monetary policy stance helps the economy cope with negative effects of the COVID-19 pandemic. While the SARB maintains its data-dependent monetary policy strategy, the agenda of key structural reforms identified by the authorities (National Treasury South Africa, 2019) needs fuller implementation to attract private investment, create jobs, boost economic growth, and make it more inclusive. Educational attainment needs to be enhanced to gain skills and employment. These are particularly important when the COVID-19 pandemic risks leaving scarring on economic activity and social conditions, and beyond that, in the context of the future of work. Looking ahead, additional waves of NIDS will help solidify the paper's findings. 


\section{REFERENCES}

Adam, K. and P. Tzamourani. 2016. "Distributional consequences of asset price inflation in the Euro Area," European Economic Review, 89, 172-92.

Aklin, Michael, Andreas Kern, and Mario Negre. 2021. “Do Central Bank Independence Increase Inequality?” World Bank Policy Research Working Paper 9522.

Albanesi, S. 2007. "Inflation and inequality," Journal of Monetary Economics, 54, 1088114.

Amaral, P. 2017. "Monetary policy and inequality," Federal Reserve Bank of Cleveland Economic Commentary, 2017-01.

Auclert, Adrien. 2019. "Monetary Policy and the Redistribution Channel," American Economic Review, 109, 6, 2333-67.

Auerbach, A. J. and Y. Gorodnichenko. 2012. "Measuring the output response to fiscal policy," American Economic Journal: Economic Policy, 4, 2, 1-27.

Bivens, J. 2015. "Gauging the impact of the Fed on inequality during the great recession," Brooking Working Paper 12.

Blanchard, Olivier. 2020. Presentation at "Monetary Policy and Inequality: COVID-19 and Beyond". Peterson Institute For International Economics.

Bulír, A. 2001. “Income Inequality: Does Inflation Matter?” IMF Staff Papers, 48, 1, 13959.

Brunnermeier, M. and Y. Sannikov. 2012. “Redistributive Monetary Policy,” Jackson Hole Symposium.

Campbell, John Y. and N. Gregory Mankiw. 1989. "Consumption, Income and Interest Rates: Reinterpreting the Time Series Evidence," In NBER Macroeconomics Annual 1989, Vol. 4, edited by Jonathan A. Parker and Michael Woodford, 185-246. Cambridge, MA: MIT Press.

Canzoneri, Matthew B., Robert E. Cumby, and Behzad T. Diba. 2007. "Euler Equations and Money Market Interest Rates: A Challenge for Monetary Policy Models." Journal of Monetary Economics, 54, 7, 1863-81.

Coibion, O., Y. Gorodnichenko, L. Kueng, and J. Silvia. 2017. “Innocent Bystander? Monetary policy and inequality," Journal of Monetary Economics, 88, 70-89.

Doepke, M. and M. Schneider. 2006. "Inflation as a redistribution of nominal wealth," Journal of Political Economy, 114, 6, 1069-97. 
Easterly, W. and S. Fischer. 2001. "Inflation and the poor," Journal of Money, Credit and Banking, 33, 2-1, 160-78.

Furceri, D., P. Loungani and A. Zdzienicka. 2018. "The effects of monetary policy shocks on inequality," Journal of International Money and Finance, 85, 168-86.

Hansen, Niels-Jakob H., Alessandro Lin, and Rui C. Mano 1. 2020 "Should Inequality Factor into Central Banks' Decisions?" IMF Working

Kaplan, Greg, Benjamin Moll, and Giovanni L. Violante. 2018. "Monetary Policy According to HANK," American Economic Review, 108, 3, 697-743.

Kaplan, Greg, Giovanni L. Violante, and Justin Weidner. 2014. "The Wealthy Hand-toMouth." Brookings Papers on Economic Activity 48, 77-153.

Kganyago, L. 2018. "Inequality and monetary policy in South Africa," South African Reserve Bank Governor's public lecture at the Nelson Mandela Lecture University.

Medina, Leandro, Andrew Jonelis, and Mehmet Cangul. 2017. "The Informal Economy in Sub-Saharan Africa: Size and Determinants," IMF Working Paper 17/156.

National Treasury South Africa. 2019. "Economic transformation, inclusive growth, and competitiveness: Towards an Economic Strategy for South Africa."

Romer, C. D. and D. H. Romer. 2004. "A New Measure of Monetary Shocks: Derivation and Implications," American Economic Review, 94, 4, 1055-84.

Schotte, Simone, Rocco Zizzamia, and Murray Leibbrandt. 2018. "A poverty dynamics approach to social stratification: The South African case," World Development, 110 , pp 88-103.

Voinea, L., H. Lovin and A. Cojocaru. 2017. "The impact of inequality on the transmission of monetary policy," Journal of International Money and Finance, 85, 236-50.

Yogo, Motohiro. 2004. "Estimating the Elasticity of Intertemporal Substitution When Instruments Are Weak," Review of Economics and Statistics, 86, 3, 797-810.

Vissing-Jorgensen, Annette. 2002. "Limited Asset Market Participation and the Elasticity of Intertemporal Substitution," Journal of Political Economy, 110, 4, 825-53.

Zizzamia, Rocco. 2020. "Is employment a panacea for poverty? A mixed-methods investigation of employment decisions in South Africa," World Development, 130, 104938. 
Table A1. Determinants of Per-Capita Household Real Consumption in South Africa: Exogenous Monetary Policy Shock, with Lagged Dependent Variable

(Estimated coefficients)

\begin{tabular}{|c|c|c|c|c|c|c|c|}
\hline Model \# & & 16 & 17 & 18 & 19 & 20 & 21 \\
\hline \multicolumn{8}{|l|}{ Macro } \\
\hline Real GDP (log) & LO. & $1.562^{* * *}$ & $2.009 * \star \star$ & $2.032^{* * *}$ & $1.983^{* \star *}$ & $2.009 * \star \star$ & $1.823^{* * *}$ \\
\hline Exogenous monetary policy shock ( $m p s$ ) & L1. & $\ldots$ & -0.053 & $-0.236^{\star \star \star}$ & 0.000 & -0.053 & $-0.457^{* * *}$ \\
\hline \multicolumn{8}{|l|}{ Micro } \\
\hline Per-capita household real cons. (log) & L1. & -0.055 & -0.068 & -0.07 & -0.07 & -0.068 & -0.069 \\
\hline \multicolumn{8}{|l|}{ Education dummy } \\
\hline No education & L1. & $-0.130^{*}$ & $-0.132^{*}$ & $-0.134^{*}$ & -0.125 & $-0.132^{*}$ & -0.105 \\
\hline Lower primary & L1. & $-0.273^{\star * \star}$ & $-0.275^{\star \star \star}$ & $-0.276^{\star * \star}$ & $-0.266^{\star * *}$ & $-0.275^{\star \star \star}$ & $-0.244^{\star * *}$ \\
\hline Upper primary & L1. & $-0.223^{* * *}$ & $-0.226^{* * *}$ & $-0.229^{* * *}$ & $-0.220^{* * *}$ & $-0.226^{\star * *}$ & $-0.212^{* * *}$ \\
\hline Secondary & L1. & $-0.091^{\star \star *}$ & $-0.091^{* * *}$ & $-0.096^{\star \star *}$ & $-0.093^{* * *}$ & $-0.091^{* * *}$ & $-0.105^{\star * *}$ \\
\hline Tertiary & L1. & $\ldots$ & $\ldots$ & $\ldots$ & $\ldots$ & $\ldots$ & $\ldots$ \\
\hline Food share of total consumption & L1. & $0.242^{* * *}$ & $0.244^{* * *}$ & $0.253^{* * *}$ & $0.244^{\star * *}$ & $0.244^{* * *}$ & $0.243^{* * *}$ \\
\hline Employment dummy & L1. & $0.051^{\star * *}$ & $0.050^{\star * *}$ & $0.051^{* \star *}$ & $0.045^{\star \star *}$ & $0.050^{\star \star \star}$ & $0.049^{\star * *}$ \\
\hline Grant recipient dummy & L1. & -0.02 & -0.022 & -0.022 & -0.021 & -0.022 & -0.022 \\
\hline \multicolumn{8}{|l|}{ Interaction with $\mathrm{mps}$} \\
\hline mps * Food share & L1. & $\ldots$ & $\ldots$ & $0.488^{\star * \star}$ & $\ldots$ & $\ldots$ & $\ldots$ \\
\hline mps * Employment dummy & L1. & $\ldots$ & $\ldots$ & $\ldots$ & $-0.123^{* *}$ & $\ldots$ & $\ldots$ \\
\hline $\mathrm{mps}$ * Grant recipient dummy & L1. & $\ldots$ & $\ldots$ & $\ldots$ & $\ldots$ & 0.001 & $\ldots$ \\
\hline mps * consumption decile 1 & L1. & $\ldots$ & $\ldots$ & $\ldots$ & $\ldots$ & $\ldots$ & $0.828^{\star \star *}$ \\
\hline mps * consumption decile 2 & L1. & $\ldots$ & $\ldots$ & $\ldots$ & $\ldots$ & $\ldots$ & $0.825^{\star \star *}$ \\
\hline mps * consumption decile 3 & L1. & $\ldots$ & $\ldots$ & $\ldots$ & $\ldots$ & $\ldots$ & $0.725^{\star * *}$ \\
\hline mps * consumption decile 4 & L1. & $\ldots$ & $\ldots$ & $\ldots$ & $\ldots$ & $\ldots$ & $0.633^{* * *}$ \\
\hline mps * consumption decile 5 & L1. & $\ldots$ & $\ldots$ & $\ldots$ & $\ldots$ & $\ldots$ & $0.436^{\star * *}$ \\
\hline mps * consumption decile 6 & L1. & $\ldots$ & $\ldots$ & $\ldots$ & $\ldots$ & $\ldots$ & $0.364^{\star \star *}$ \\
\hline mps * consumption decile 7 & L1. & $\ldots$ & $\ldots$ & $\ldots$ & $\ldots$ & $\ldots$ & $0.244^{\star \star}$ \\
\hline $\mathrm{mps}^{*}$ consumption decile 8 & L1. & $\ldots$ & $\ldots$ & $\ldots$ & $\ldots$ & $\ldots$ & $0.255^{\star *}$ \\
\hline mps * consumption decile 9 & L1. & $\ldots$ & $\ldots$ & $\ldots$ & $\ldots$ & $\ldots$ & $0.317^{\star \star \star}$ \\
\hline mps * consumption decile 10 & L1. & $\ldots$ & $\ldots$ & $\ldots$ & $\ldots$ & $\ldots$ & $\ldots$ \\
\hline \multicolumn{8}{|l|}{ Other controls } \\
\hline Location & L1. & yes & yes & yes & yes & yes & yes \\
\hline Location*real GDP & L1. & yes & yes & yes & yes & yes & yes \\
\hline Consumption decile & L1. & yes & yes & yes & yes & yes & yes \\
\hline Individual effects & $\ldots$ & yes & yes & yes & yes & yes & yes \\
\hline \# of Obs. & & 26,876 & 26,876 & 26,876 & 26,876 & 26,876 & 26,876 \\
\hline Cross section $(\mathrm{N})$ & & 6,719 & 6,719 & 6,719 & 6,719 & 6,719 & 6,719 \\
\hline Time series $(T)$ & & 4 & 4 & 4 & 4 & 4 & 4 \\
\hline Adjusted $\mathrm{R}^{\wedge} 2$ & & 0.115 & 0.116 & 0.117 & 0.116 & 0.116 & 0.127 \\
\hline
\end{tabular}

Sources: Haver, NIDS, and author's calculations.

Note: This table reports estimated results from equation (3). Dependent variable is per-capita household real consumption level in log. L0 and L1 signify contemporaneous value and one period lag. ${ }^{* * *}$, ${ }^{*}$, and * when statistically significant at the 1,5, and 10 percent levels. Memo item reports the total effects of $r p o l$ is calculated using Stat command lincom. 